\title{
A Review of Carbonatite Occurrences in Italy and Evaluation of Origins
}

\author{
Angelo Paone \\ Department of Earth Sciences, Pusan National University, Busan, South Korea \\ Email: angelo.paone1@gmail.com
}

Received February 22, 2013; revised March 22, 2013; accepted April 22, 2013

Copyright (C) 2013 Angelo Paone. This is an open access article distributed under the Creative Commons Attribution License, which permits unrestricted use, distribution, and reproduction in any medium, provided the original work is properly cited.

\begin{abstract}
This review and evaluation seeks to clarify the controversial origins of the Umbria-Latium Ultra-alkaline District (ULUD) and the Vulture carbonatitic occurrence (Intramontane Ultra-alkaline Province, IUP) and their relation to the Roman Comagmatic Province (RCP). Generally, the geochemical and isotopic features of the IUP can be linked to those of the RCP. Hence, the rocks of the ULUD district, together with part of the Tuscan and Roman Province generated in the last $2 \mathrm{Ma}$ can be ascribed to a complex interplay of two subduction events related to magmatism associated with the European and Adria slabs associated with the effect of a slab window below the Italian Peninsular. Carbonate sediments together with pelagic-terrigenous sediment played a major role in the metasomatism of the mantle wedge beneath the IUP, and perhaps all along the transect from southern Italy (Eolian Islands magmatism) to north-central Italy (Tuscan and Umbria magmatism). A diffuse $\mathrm{CO}_{2}+\mathrm{H}_{2} \mathrm{O}$ metasomatic front produced the condition necessary for the formation of carbonatitic magmatism. However, even where carbonatites are related to continental rift system (i.e., OIB), an origin for MORB-sediment convective recycling melting in the mantle has been hypothesized [i.e., 1].
\end{abstract}

Keywords: Carbonatites; Isotopes; Sediments; Arc System; Roman Comagmatic Province

\section{Introduction}

Recent work by [2] pointed out that there are more than 500 carbonatitic occurrences worldwide which causes new interest for studying them and understanding the associated genetic processes. To enlighten further the understanding of carbonatite genesis, the differences between extrusive and intrusive carbonatites have to be taken in account [3]. The relationship between the Roman Comagmatic Province and the Pleistocene rocks of the Ultra-alkaline Latium-Umbria District (ULUD) and Vulture volcano carbonatitic outcrops [e.g., 4,5] is investtigated from geochemical, petrological and tectonic points of view in order to better understand the origin of the carbonatitic magmas erupted in Italy. Particular emphasis is given to the petrogenesis of the Italian carbonatites and their links to the Italian tectonic system. An origin for the carbonatites is suggested based on the available literature [i.e., 4]. The origin of carbonatitic rocks is still debated: a deep-seated origin - plume hypothesis [6] versus a shallower origin-lithospheric metasomatised mantle [i.e., 7]. Moreover, Italy seems anomalous to find carbonatitic rocks, and their presence can play a major role 1) to shed light on the Italian tecto- nic setting [e.g., 8-12], and 2) to contribute to the understanding of the genesis of carbonatitic rocks. There is considerable research that links recycled materials with carbonatitic rocks through metasomatism in the upper mantle. [13] demonstrate that carbonate remains as a refractory phase in rutile eclogite residue in equilibrium with andesite melt in subduction regimes. [14-16] experimentally show that deep global cycling of carbon, with storage in the mantle, can occur. The recycling character of the carbonated eclogite triggers metasomatic processes in the upper mantle. The processes may have a role in metasomatically enriching and carbonating parts of the upper mantle, producing sources suitable for subsequent production of silica undersaturated silicate liquids and carbonatites that are subsequently emplaced in the crust.

The vast literature on the Italian peninsula has focused attention on two conflicting hypothesis differing over the role of recent slab subduction: 1) The origin of the PlioPleistocene Quaternary volcanism is a consequence of Neogene subduction of the Adria plate below the Tyrrhenian sea [e.g., 17-20 and references therein]; and 2) The presence of the carbonatitic rocks (ULUD and Vulture, i.e. IUP) and their tectonic setting is taken to sug- 
gest that the Italian peninsula is associated with postcollisional rifting [e.g., 21-23 and references therein] with the Italian magmas being derived from a deep mantle plume $[9,10]$. However, the hypothesis of the presence of the European plate dipping southward [e.g., 24-26] and a recent subducted slab dipping westward are supported by geophysical studies [e.g., 20,24,25,27-35].

\subsection{A Framework of the Tectonic Setting and Magmatic Activity in the Roman Comagmatic Province}

Subduction of the Adria plate started in the Early Oligocene-Early Miocene and developed to the east of the former Alpine Chain. The Apenninic accretionary prism formed at the front of the pre-existing Alpine back-thrust belt. The associated back-arc extension migrated eastward and boudinaged the Alpine nappe stack [36]. Kinematic and geophysical data support the presence of an eastward migrating asthenospheric wedge at the subduction hinge of the roll-back Adriatic plate [37]. The rifting started to the east of Corsica and Sardinia, and generated two major basins in the southern Tyrrhenian, i.e., the Magnaghi-Vavilov basin (7 - 3.5 Ma) and the Marsili basin (1.7 - 1.2 Ma). Thus, the Apennine subduction took place during the last $30 \mathrm{Ma}$.

Beneath Central Italy, there is clear evidence of lithospheric roots, reaching at least of $130 \mathrm{~km}$ deep over a width of $120 \mathrm{~km}$, below the western edge of the thick sedimentary basins (75 $\mathrm{km}$ deep) to below the extension-compression transition area (200 km deep). The crust exhibits clear layering and lateral variation in thickness: about $25 \mathrm{~km}$ below the Tuscan Metamorphic Complex (TMC), $30 \mathrm{~km}$ below the extensional thick sedimentary basins, and $35 \mathrm{~km}$ below the Umbria-Marche geological domain (UMD). The lithospheric mantle (lid) is thin (about $30 \mathrm{~km}$ ) below the TMC, but it is about $70 \mathrm{~km}$ thick below UMD. All along the profile a mantle wedge, with thickness of about $20 \mathrm{~km}$, lies between the crust and the lid. The wedge exhibits very low mantle velocities and hence may well decouple the underlying lid from the crust. Young magmatism at the surface and high heat fluxes in the region where this low-velocity upper mantle wedge gets shallower and attains its maximum thickness (TMC) suggest that this layer may represent a partially molten mantle, in agreement with petrological and geochemical data [38]. The subcrustal earthquakes [31,39] seem to cluster in the shallower part of the thick Adriatic lid and in the eastern part of the lithospheric root, consistently with a slab-like geometry, while the part of the lithospheric root and thin lid to the west seems to be almost free of seismic activity. This is seen in many Pwave tomographic images indicating the presence of a high-velocity body of significantly larger volume than that defined by earthquake foci. There are two possible explanations for the existence of a large lithospheric volume with laterally varying mechanical properties under North-Central Italy: 1) the presence of lateral variations in the stiffness of the lithosphere, consistent with the heat flow distribution, and/or 2) the coexistence of the Adria west-dipping remnant slab, with a possible relic of the old Alpine east-dipping slab consistent with geological $[36,40]$ and seismic reflection data $[41,42]$.

Volcanic activity in this region included MORB, island arc tholeiites, calc-alkaline, high-K calc-alkaline and shoshonitic products, $\mathrm{Ca}-\mathrm{Na}$ - and $\mathrm{K}$-alkaline rocks [5, 43]. Carbonatitic rocks have been recently suggested to form a new Province (the Intramontane Ultra-alkaline Province [IUP]) formed by the Umbria Latium Ul-traalkaline District and some volcanic deposits of Vulture volcano, east of the Roman Province and Campanian District (Figure 1; e.g., [4,5 and references therein]). Particularly, potassic and ultrapotassic magmatism (Roman Comagmatic Province, RCP) represents the most characteristic magmatic feature of the Tyrrhenian area. It spans a time interval between $4 \mathrm{Ma}$ and the present time. Potassic and ultrapotassic rocks have variable petrochemical affinity that range from Roman type potassic series (KS), to Roman type high-potassium series (HKS), lamproites, and kamafugites [e.g., 44]. KS and HKS rocks

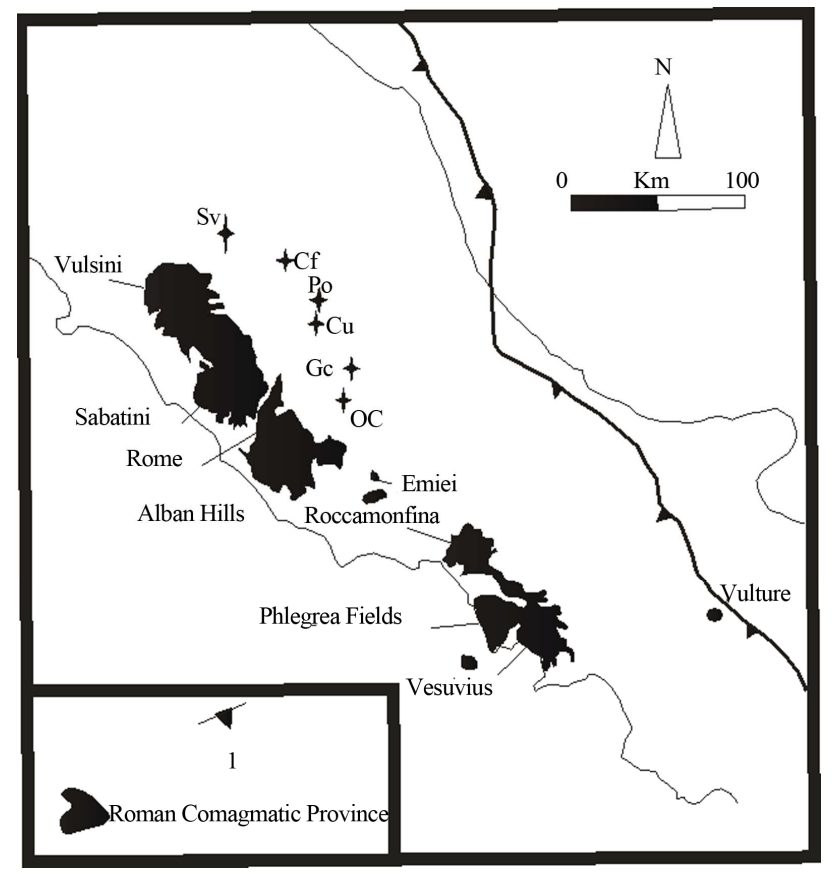

Figure 1. Location map of the Roman Comagmatic Region. Stars represent Umbria Latium Ultralkaline District (ULUD) volcanoes. Symbols: 1: main active compression; Sv, San Venanzo; Cf, Colle Fabbri; Po, Polino; Cu, Cupaello; GC, Grotta del Cervo; OC, Oricola-Camerata Nuova (Modified from [57]. 
occur in the Roman province, whereas lamproites are present in Tuscany and Corsica, and kamafugites form few centers east of the Roman province [e.g., 45-47]. The $\mathrm{KS}$ rocks are similar to shoshonites, whereas the HKS shows a very strong enrichment in potassium and incompatible elements. However, both the KS and HKS have relatively low contents of high field strength elements (i.e., $\mathrm{Nb}$ and Ta; HFSE). Kamafugites show similar incompatible element patterns as HKS, but they are more strongly under-saturated in silica and have higher $\mathrm{CaO}$ and lower $\mathrm{Na}$ contents than the HKS.

\subsection{Italian Carbonatitic Magmatism Related to the Roman Comagmatic Province}

\subsubsection{A Petrographic Outline of ULUD and Vulture Volcanic Deposits}

The ages of the ULUD deposits range between 0.53 and $0.265 \mathrm{Ma}$ (i.e., San Venanzo and Polino) (Stoppa and Villa, 1991). Carbonatitic rocks include lithotypes with modal calcite ranging from $\sim 10 \%$ to $>50 \%$ (carbonatitic $20 \%-50 \%$, carbonatites $>50 \%$ ). The San Venanzo volcano is composed of three vents: the San Venanzo maar; the Pian di Celle tuff ring, and the Celli tuff cone [48]. The pyroclastic rocks consist of carbonatitic tuffs and tuffisites. These deposits contain spherical and plastically deformed lapilli and bombs. The tuffs may contain up to $50 \%$ of fine grained calcite, the other minerals present are melitite, leucite, and olivine with a glassy groundmass. The lapilli are concentric with porphyritic carbonate-rich melilitite material cored with forsteritic olivine. The lapilli are also embedded in fine-grained carbonate rich matrix. There are lava flows characterised as porphiritic kalsilite phologopite-olivineleucite melilitite (kamafugite). These rocks are composed of olivine phenocrysts within a groundmass composed of leucite, kalsilite, melitite, phlogopite, and clinopyroxene, accessory minerals are perovskite, zeolites, and carbonates [49 and references therein]. Colle Fabbri (Figure 1) consists of two vent-opening explosions that formed subaerial breccias with two stages of intrusion: 1) dykelet swarms of melilitic lava, and 2) a massive holocrystalline, medium-grained plug (i.e., leucite-wollastonite melilitolite of [50] or alternatively called euremite from [51]. This outcrop (leucite-wollastonite melilitolite) has been interpreted by [52] as melilite-bearing pyrometamorphic rocks (paralavas) due to coal fires. This interpretation has been challenged by [53], and [54] reaffirming that the Colle Fabbri outcrop is of magmatic origin. The leucite-wollastonite melilitolite is medium grained and equigranular, with finegrained margins consisting partly of calcite-zeolite filled ocelli. The rock is composed of melilite euhedra, poikilitically enclosing wollastonite and intergranular leucite. Melilite also intergrows with leucite and kalsilite. High temperature, accessory phases are garnet (schorlomite) and apatite. Anorthite is also common and occurs in single crystals. The order of crystallization is wollastonite, melilite, anorthite, Ti-magnetite, schorlomite, and leucite. Quench clinopyroxene is present at the margins. Latestage zeolites and peculiar carbonate-silicate-sulphate are very abundant in the melilitolite and the host rock [54, 55].

The Polino diatreme is filled by a breccia consisting of calcite-carbonatite lapilli and bombs [56]. The matrix is a calcite-cemented tuffsite composed of concentric layered lapilli (spin lapilli). The massive carbonatite consists of xenocrysts of forsterite that often have a monticellite reaction rims, xenocrysts of phlogopite, and microphenocrysts of Th-perovskite, Zr-schorlomite, Ti-magnetite within a cryptocrystalline calcite matrix. Modal analyses has $53 \%$ calcite (10\% vesicles plus groundmass), monticellite at $23 \%$, Th-perovskite plus Ti-magnetite at $9 \%$, olivine at $6 \%$, phlogopite at $6 \%, \mathrm{Zr}$-schorlomite at $2 \%$, and apatite $<1 \%$. Cupaello is formed by a small vent or fracture from which a sequence of carbonatitic and phonolitic pyroclastic rocks and kalsilite melilitite (coppaelite) lava flow erupted. The pyroclastic level is composed of bombs of melilitite with a micritic carbonate matrix. The coppaelite is porphiritic and contains xenocrysts of corroded phlogopite and diopside in a hypocrystalline matrix of diopside, kalsilite, melilite, monticellite, spinel, perovskite, götzenite, khibinskite, apatite, and glass. The coppaelite ranges in composition from kalsilitite to kalsilite melilitite.

The Grotta del Cervo (Figure 1) locality is a pyroclastic deposit in the Pietrasecca karst-cave system. The Grotta del Cervo mela-foiditic tuff is composed of lapilli ash tuff, welded lapilli, ultramafic xenoliths, cognate lithics, and pelletal lapilli [57]. The welded lapilli consist of diopside, leucite, haüyne, eastonite, melanitic garnet, LREES-apatite, magnetite, kalsilite, and olivine. The chemistry of Grotta del Cervo characterize the rock as kamafugite. The lapilli ash tuff contains more than $10 \mathrm{wt} \%$ of carbonate and is therefore a carbonatic kamafugite. The Carsoli-Oricola volcanic field (Figure 1) consist of six vents (tuff rings). Oricola carbonatite tuffs consist of plastically moulded lapilli [58]. They are composed of fragments of olivine, diopside, phlogopite and apatite plus leucititic glass shards. Silicate fragments are immersed in a micro-cryptocrystaline matrix of Ca-carbonate. Finally, in the Vulture (Figure 1) occurrence, the Monticchio diatremic activity produced several maars (age: $0.13 \mathrm{Ma}$ ) which erupted carbonatite-melilitite lapilli in carbonatitic matrix [59]. Melititic lapilli and bombs in carbonatitic ash tuff form the main part of the deposits. Peridotite nodules of spinel wherlites and lherzolites are also present [60]. Some carbonatite concentric strata are preserved around melilitite lapilli. The mineral assemblage of the 
juvenile fragments (blocks of lapilli) consist of xenocrysts of Al-Cr diopside, residual forsterite, Cr-spinel, and very rare $\mathrm{Mg}$-garnet. The groundmass contains melilite, spinel with magnetite rims, Baphlogopite, olivine, hauyne-lazurite, apatite, calcite, and perovskite and pyrite veins.

\subsubsection{Geochemical Outline of the IUP Related to the RMP}

The kamafugites of central Italy are ultra-basic, silica undersaturated, peralkaline rocks $(\mathrm{K}+\mathrm{Na} / \mathrm{Al}=1.2-1.3)$ containing a typically plagioclase-free assemblage of kalsilite, leucite \pm nepheline. They also have high $\mathrm{CaO}$ contents $(\sim 15 \mathrm{wt} \%), \mathrm{Mg} \#(75-81)$ and $\mathrm{K}_{2} \mathrm{O} / \mathrm{Na}_{2} \mathrm{O}$ ratios compared with other volcanic rocks of the Roman Comagmatic Province. The carbonate is high enough to form carbonate minerals, essential calcite and monticellite, plus xenocrysts of phlogopite and olivine [5]. The mafic minerals are melilite, and diopside characterized by high $\mathrm{Mg}, \mathrm{Ni}, \mathrm{Cr}$ contents. Olivine melilitites $\left(\mathrm{SiO}_{2}\right.$ $<41 \%)$ and calciocarbonatites $\left(\mathrm{SiO}_{2}<12 \%\right)$, although sharing many characteristics with leucitites, have an even more primitive and undersaturated character, including very high $\mathrm{Cr}+\mathrm{Ni}$ contents $(<1000 \mathrm{ppm})$. They carry phlogopite in the mantle debris suggesting a source of carbonated phlogopite peridotite (the same source is invoked experimentally by [61]). The carbonatitic rocks and associated lithologies (e.g. melilitite, melilitolite, and kamafugite) show a wide range in $\mathrm{CaO}$ contents from $37.7 \mathrm{wt} \%$, to $\sim 2.2 \mathrm{wt} \%$. The high values are also present in the melilitolite rocks. $\mathrm{Al}_{2} \mathrm{O}_{3}$ ranges between 23.3 and $1.82 \mathrm{wt} \%$, and $\mathrm{TiO}_{2}$ is scattered and ranges between 2.8 and $0.2 \mathrm{wt} \%$. $\mathrm{MgO}$ and $\mathrm{K}_{2} \mathrm{O}$ show similar features.

Multi-element diagrams normalized to primitive mantle show that kamafugite and carbonatite rocks have overlapping concentrations. In particular, the Polino carbonatite-San Venanzo kamafugite and Grotta del Cervo
kamafugite-Oricola carbonatite pairs have similar patterns [58 and references therein]. A petrological association is also confirmed by major and trace element plots, which show an evolutionary trend with a gap between Polino and some Cupaello samples (richer in Ca content; Oricola also get closer to this field) and the rest of the IUP (e.g., San Venanzo; $\mathrm{CaO}-\mathrm{SiO}_{2}$ diagram). As discussed below, this gap may be the result of immiscibility between the most silicic and carbonatitic rock series. Multi-element diagrams also show 1) that the patterns of Melilitite lava, carbonate-rich rock from Cupaello and leucite tephrite from Vulsini (Roman Comagmatic Province) are broadly similar [62], and 2) that the wide compositional ranges observed among carbonatitic, melilititic, kamafugitic and potassic and ultrapotassic rocks, may be due to heterogeneity in the source and/or various extent of melting proportion. Such a source may have been metasomatised by fluid and sediments released by the slab in subduction [63 and references therein], and, indeed there is evidence for a metasomatised mantle beneath Italy [64].

The ${ }^{143} \mathrm{Nd} /{ }^{144} \mathrm{Nd}-{ }^{87} \mathrm{Sr} /{ }^{86} \mathrm{Sr}$ diagram (Figure 2) shows the relationship between most of the Italian volcanic rocks, and the Italian Sr-Nd isotopic array is highlighted, as is the ULUD (Umbria-Latium ultra-alkaline district, [5, 21] (carbonatites, melilitites; [65]). [65] compared the $\mathrm{Sr}-\mathrm{Nd}$ isotope ratios $\left({ }^{87} \mathrm{Sr} /{ }^{86} \mathrm{Sr}: 0.70970\right.$ - 0.7119 , ${ }^{143} \mathrm{Nd} /{ }^{144} \mathrm{Nd}$ : $\left.0.5119-0.5122\right)$ of the ULUD volcanic rocks to kamafugites, orangeites and lamproites. The Ugandan kamafugites do not overlap with the Italian kamafugites, melilitites and carbonatites. However, on the basis of mineralogy and major elements, [66] classify the Chinese carbonatite-kamafugite association together with associated Polino (Italy) and Fort Portal (Uganda). The ULUD rocks plot between the field of South African orangites and Western Australian lamproites. However, the ULUD carbonatite-melilitite of S. Venanzo, Polino, Colle Fabbri

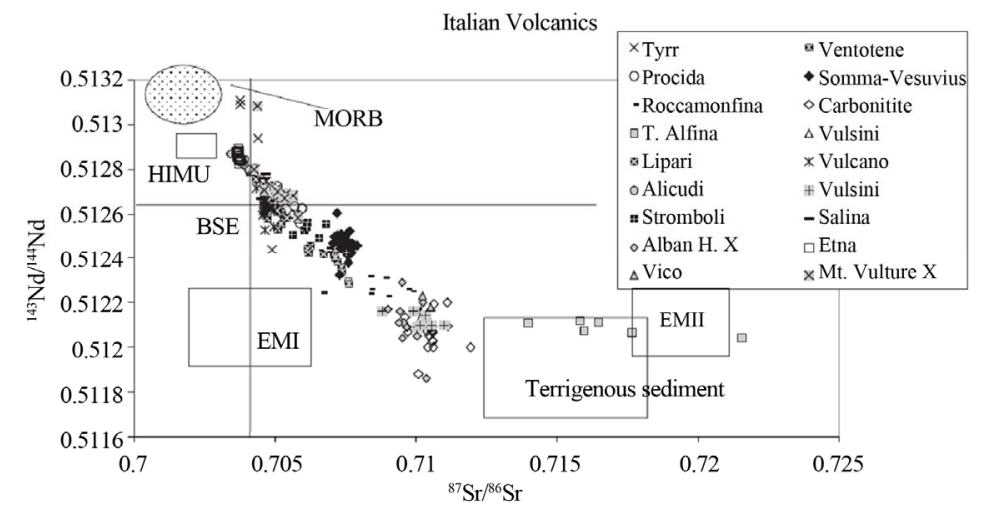

Figure 2. ${ }^{143} \mathrm{Nd} /{ }^{144} \mathrm{Nd}-{ }^{87} \mathrm{Sr} /{ }^{86} \mathrm{Sr}$ diagram. MORB, HIMU, EMI, EMII and BSE are from [147]. Tyrrhenian platform volcanics, Ventotene, Procida, Somma-Vesuvius, Roccamonfina, Carbonatite (ULUD), T.Alfina, Vulsini, Lipari, Alicudi, Vulcano, Stromboli, Salina, Alban Hills, Etna and Vico are from ([71] and references therein, [65,77] and references therein; Mt. Vulture xenolith are from [70]. Terrigenous sediment field from [148]. 
(leucite-wollastonite melilitolite) has been interpreted by [52] as melilite-bearing pyrometamorphic rocks (paralavas). This interpretation has been challenged by [53], reaffirming that Colle Fabbri outcrop is of magmatic origin. First, homogenization temperatures of inclusions in wollastonite, anorthite and clinopyroxene show that the studied Colle Fabbri rocks started to crystallize at temperatures greater then $1250^{\circ} \mathrm{C}$ which are clearly in the igneous temperature range. Second, the complete melting of clay country rocks would need temperatures higher than $1300^{\circ} \mathrm{C}$ which are unreasonable for underground lignite fires [67].

IUP rocks are isotopically off the worldwide car- bonatites array (higher ${ }^{87} \mathrm{Sr} /{ }^{86} \mathrm{Sr}$ ) [68] and they fall off the Ugandan kamafugites trend [69]. On the other hand, the same rocks fall on the $\mathrm{Sr}-\mathrm{Nd}$ isotopic Italian array (Figure 2), isotopically similar to some of the Roman volcanoes (i.e., Alban Hills, Vulsini, Vico) and other potassic continental rocks such as orangeites and lamproites. In addition, [70] showed that the $\mathrm{Sr}-\mathrm{Nd}$ isotopic composition $\left({ }^{87} \mathrm{Sr} /{ }^{86} \mathrm{Sr}: 0.7042-0.7058,{ }^{143} \mathrm{Nd} /{ }^{144} \mathrm{Nd}: 0.51260-\right.$ 0.5131 ) of the mantle xenoliths from the Mt. Vulture carbonitite-melilitite volcanic rocks have lower $\mathrm{Sr}$ and higher $\mathrm{Nd}$ isotopic ratios than the ULUD isotopic ratios but they are isotopically similar to the Campanian Volcanic District (i.e., Campi Flegrei and Somma-Vesuvius, [71, 72]). The $\mathrm{Pb}$ isotopic data [73] are reported in Table 1 with the respective petrographic rock types for the carbonatitic occurrences and associate silicate rocks. The ${ }^{87} \mathrm{Sr} /{ }^{86} \mathrm{Sr}-{ }^{206} \mathrm{~Pb} /{ }^{204} \mathrm{~Pb}$ and ${ }^{143} \mathrm{Nd} /{ }^{144} \mathrm{Nd}-{ }^{206} \mathrm{~Pb} /{ }^{204} \mathrm{~Pb}$ diagrams (Figures 3(a) and (b)) show that the Italian carbonatite field falls on the Italian isotopic array with radiogenic $\mathrm{Sr}$ isotopes and unradiogenic $\mathrm{Nd}$ isotopes and ${ }^{206} \mathrm{~Pb} /{ }^{204} \mathrm{~Pb}$ of 17.9 - 18.87. These diagrams also suggest that the Italian isotopic array is made by the following end-members: A) a mixtures of DMM and HIMU, the HIMU is likely because the data points towards the HIMU end-member. This character is clear on the $\mathrm{Sr}-\mathrm{Nd}-\mathrm{Pb}$ isotopic space of $[9,10]$ and B) an upper crustal component characteristic of the Italian enriched upper mantle. Furthermore, the ${ }^{208} \mathrm{~Pb} /{ }^{204} \mathrm{~Pb}-{ }^{206} \mathrm{~Pb} /{ }^{204} \mathrm{~Pb}$ and ${ }^{207} \mathrm{~Pb} /{ }^{204} \mathrm{~Pb}-{ }^{206} \mathrm{~Pb} /{ }^{204} \mathrm{~Pb}$ diagrams (Figure 4) show a straight line with the Italian carbonatites plotting with lower radiogenic $\mathrm{Pb}$ isotope values than the Etna field and overlapping with the oceanic sediments field. The $\mathrm{Pb}$ isotopic regional components characterizing the Italian carbonatites overlap the sediments and the Eolian arc fields components. Sardinia trends towards EMI, and Etna plots below the NHRL into the Pietre Nere, and Iblei fields. The carbonatites seem to have an EM2 com- ponent and it is suggested here that it reflects mixing between MORB and oceanic sediments. In other words, they are dominated by sediments as suggested by EM2 for $\mathrm{Nd}$ and $\mathrm{Sr}$ isotopes.
However, further insight can be gained by studying the three isotope $\mathrm{Ne}$ diagram $\left({ }^{20} \mathrm{Ne} /{ }^{22} \mathrm{Ne}-{ }^{21} \mathrm{Ne} /{ }^{22} \mathrm{Ne}\right.$, Figure 5). This diagram shows that S. Venanzo, Cupaello, Polino and Vulture trend towards a crustal component as in [74 and references therein] for the Eolian arc and the Somma-Vesuvius volcano $[75,76]$. Hence, the ULUD falls broadly with the leucite-bearing rocks [77].

The Sr-Nd-Pb isotopic variation for the ULUD [65], included Mt. Vulture mantle xenoliths associated with the carbonatitic-melilitic Monticchio magmas [70], and it is in accordance with the Italian isotopic array. These isotope ratios values vary in parallel to the Roman and Campanian regions from Umbria-Latium region to the

Table 1. Pb isotopic compositions of the carbonatitic occurences in Italy and associate silicate rocks

\begin{tabular}{|c|c|c|c|c|}
\hline Samples & & ${ }^{206} \mathrm{~Pb} /{ }^{204} \mathrm{~Pb}$ & ${ }^{207} \mathbf{P b} /{ }^{204} \mathbf{P b}$ & ${ }^{208} \mathrm{~Pb} /{ }^{204} \mathrm{~Pb}$ \\
\hline \multicolumn{5}{|l|}{ Vulture } \\
\hline VUT-106 & $\begin{array}{c}\text { Phonolitic foidite } \\
\text { lava }\end{array}$ & 19.296 & 15.69 & 39.301 \\
\hline VUT-255 & $\begin{array}{l}\text { Malanite phonolite } \\
\text { pumice }\end{array}$ & 19.162 & 15.673 & 39.119 \\
\hline VUT-1523 & $\begin{array}{l}\text { Melilite bearing } \\
\text { foidite lava }\end{array}$ & 19.28 & 15.68 & 39.253 \\
\hline VUT-69 & $\begin{array}{l}\text { Leucite melilitolite } \\
\text { dyke }\end{array}$ & 19.457 & 15.711 & 39.509 \\
\hline \multicolumn{5}{|l|}{ Polino } \\
\hline IT120 & Ca carbonatite tuff & 18.774 & 15.69 & 39.003 \\
\hline IT121 & $\begin{array}{l}\text { massive } \mathrm{Ca} \\
\text { carbonatite }\end{array}$ & 18.767 & 15.679 & 38.978 \\
\hline \multicolumn{5}{|l|}{ Oricola } \\
\hline OR1 & Ca carbonatite tuff & 18.745 & 15.681 & 38.996 \\
\hline OR1b & $\begin{array}{c}\text { Ca carbonatite } \\
\text { lapillus }\end{array}$ & 18.744 & 15.68 & 38.995 \\
\hline \multicolumn{5}{|l|}{$\begin{array}{c}\text { San } \\
\text { Venanzo }\end{array}$} \\
\hline VEN-5 & $\begin{array}{c}\text { Kal lc ol melilitite } \\
\text { lava }\end{array}$ & 18.742 & 15.662 & 38.929 \\
\hline VEN-10 & $\begin{array}{c}\text { Kal lc ol melilitite } \\
\text { lava }\end{array}$ & 18.747 & 16.667 & 38.952 \\
\hline \multicolumn{5}{|l|}{$\begin{array}{l}\text { Colle } \\
\text { Fabbri }\end{array}$} \\
\hline CF-13 & $\begin{array}{l}\text { Lc woll melilitolite } \\
\text { plug }\end{array}$ & 18.747 & 15.66 & 38.747 \\
\hline CF-18 & $\begin{array}{l}\text { Lc woll melilitolite } \\
\text { plug }\end{array}$ & 18.868 & 15.683 & 38.946 \\
\hline \multicolumn{5}{|l|}{ Cuppaello } \\
\hline $\mathrm{COP}-4$ & $\begin{array}{l}\text { Melilite kalsilitite } \\
\text { lava }\end{array}$ & 18.75 & 15.676 & 38.963 \\
\hline COP-8 & $\begin{array}{c}\text { Melilite kalsilitite } \\
\text { lava }\end{array}$ & 18.755 & 15.68 & 38.972 \\
\hline
\end{tabular}

The abbriviattion are as follow: Kal, kalsilite; lc, leucite; woll, wollastonite; ol, olivine. 

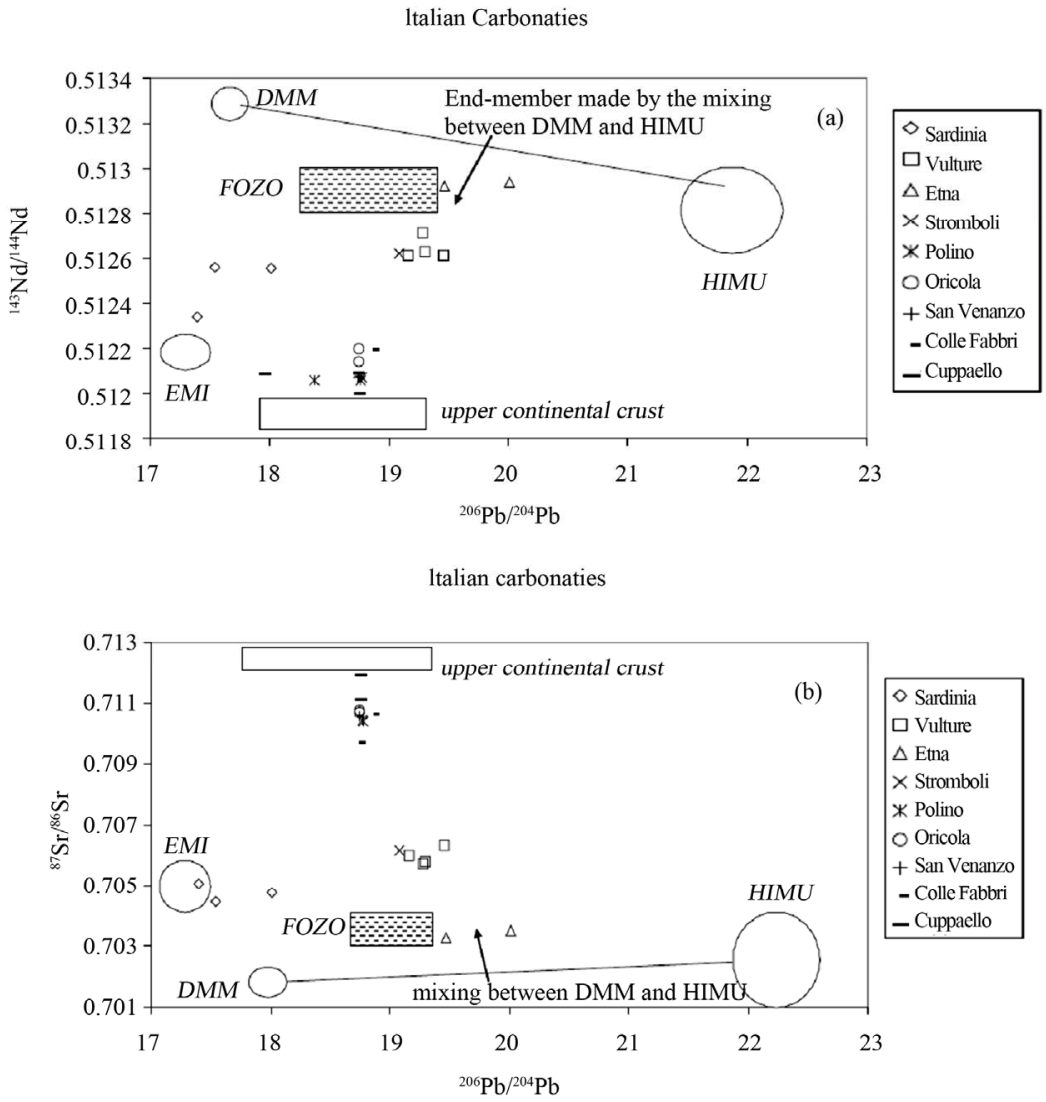

Figure 3. (a) ${ }^{143} \mathrm{Nd} /{ }^{144} \mathrm{Nd}^{-206} \mathrm{~Pb} /{ }^{204} \mathrm{~Pb}$ diagram. The carbonatitic, Vulture, Etna, and Sardinia data are unpublished data. The fields of DMM, HIMU, and EMI, are from [147]. The FOZO field is from [93]. (b) ${ }^{87} \mathrm{Sr} /{ }^{86} \mathrm{Sr}-{ }^{206} \mathrm{~Pb} /{ }^{204} \mathrm{~Pb}$ diagram. The isotopic data and the fields are as in the Figure $2 \mathrm{~A}$. The upper continental crust field is from [77,148 and references therein].

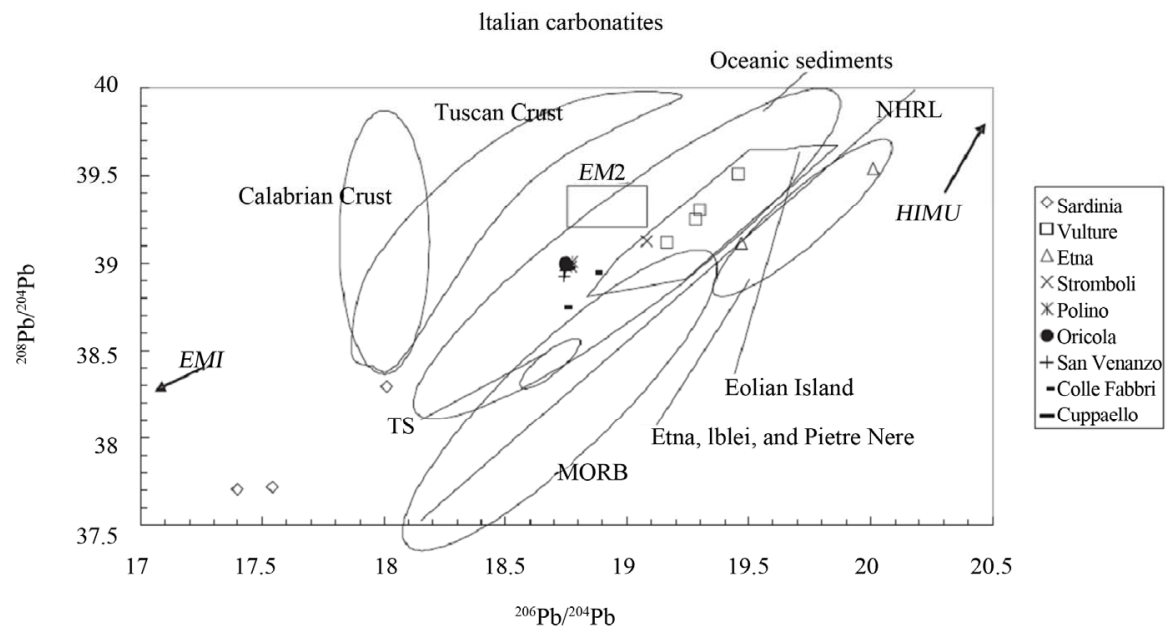

Figure 4. ${ }^{208} \mathrm{~Pb} /{ }^{204} \mathrm{~Pb}-{ }^{206} \mathrm{~Pb} /{ }^{204} \mathrm{~Pb}$ diagram. The fields of Tuscan and Calabrian crusts, oceanic sediments, MORB, Tyrrhenian Sea floor (TS), Na-alkaline and calc-alkaline volcanic rocks from South Italy, and NHRL are reported. Fields and lines are drawn after [77 and references therein].

Mt. Vulture carbonatitic occurrence [70,78,79]. In addition, calcite in sövite ejecta ( $\mathrm{O}$ and $\mathrm{C}$ isotopes) from $\mathrm{Vul}-$ ture [80] lies close to the "mantle box" and has clearly undergone minimal deuteric-hydrothermal exchange, whereas the Vulture carbonate-rich extrusive tuffs plot within, or close to, the outlined field of carbonatitic tuffs from elsewhere, as do the Cuppaello and San Venanzo tuffs and the Polino tuffisite. Whatever the mechanism 


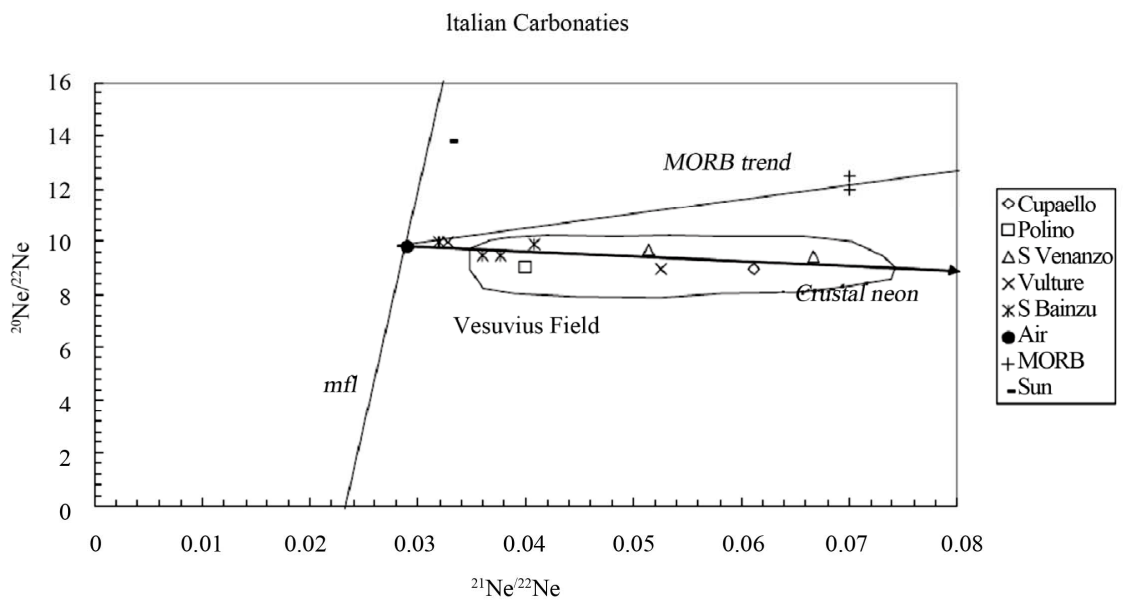

Figure $5 .{ }^{20} \mathrm{Ne} /{ }^{22} \mathrm{Ne}-{ }^{21} \mathrm{Ne} /{ }^{22} \mathrm{Ne}$ diagram. The Neon isotope data are unpublished data.

for these changes, which have been addressed in a number of papers [e.g., 81-84], it is important to note that carbonate in the Italian extrusive carbonatites have similar trends to extrusive carbonatites from other localities. However, The IUP $\delta^{13} \mathrm{C}$ (PDB) ranges from -16 to -2 which may also have derived by a mixing between MORB and Marine sediments components whereas $\mathrm{O}$ isotopes may have affected by deuteric-hydrothermal exchange $\left(\delta^{18} \mathrm{O} \sim 22\right)$.

Additionally, the chondritic-REE normalised plot of the Italian carbonatites [5] show a characteristic Eu negative anomaly similar to those of the Roman Province [85, 86] and Campanian volcanic District [72]. Such Eu anomalies are attributed to mixing between MORB component and various proportion of clay-shale sediment [72, $85,87,88]$ at upper mantle levels. More evidence come from the work of [89] on the Betic Cordillera (Southern Spain) where Sr-Eu anomalies together with the Sr-Nd isotope data are interpreted as being due to subduction metasomatism from terrigenous sediments. Moreover, Eu anomalies are not a common feature in the world-wide carbonatites [90,91]. However, Laiwu-Zibo carbonatites from western Shandong Province, China [92] show the presence of a small Eu anomaly similar to the Italian carbonatites. These carbonatites are also characterized by the similar Sr-Nd isotopic composition as the ULUD.

\section{Discussion}

The controversy identified by $[8,65]$ is focused on the relation between the ULUD and the Roman Magmatic Province origins and the related hypothesed tectonic setting. Particularly, [8] state that the Italian (IUP) and Ugandan (East African Rift Zone) volcanoes have sampled similar mantle conditions. Although the large scale geodynamic regimes are in total contrast, as are the deep mantle tomographic structures, the crucial common factor at the igneous province level is extensional tectonics. Extension, promoting release of volatiles (i.e., $\mathrm{H}_{2} \mathrm{O}, \mathrm{CO}_{2}$ ). [93] argue for a deep seated origin given the similarity of the isotopic signatures to FOZO (Focal Zone) and HIMU to carbonatites worldwide. $[9,10]$ attempt to model with a geochemical and isotopical approach, the Italian carbonatites to the rest of the Italian magmatism by a large plume centred in the Tyrrhenian Sea and extending from beneath the western Alps through the Italian mainland westwards under the Sardinia and Corsica. The three isotopic end-members involved are FOZO, EMI and an Italian enriched mantle (ITEM as defined by $[9,10])$. The same trend is observed by $[62,94]$ with different interpretations of the end-members: DMM, HIMU and an upper crust component. [94] envision a slab window below the Italian peninsula which is also supported by slab detachment tomographic data (e.g., $[24,95,96]$. This structure would have permitted mixing of the HIMU (AOC, altered ocean crust) and DMM (mantle wedge) with and isotopic enriched component derived from the subducted sediments from the European and the Adria plates.

As discussed above, there are some inconsistencies between the general geochemistry of the carbonatites (ULUD) and the Italian tectonics which need some clarification. 1) The geochemical framework of [97] emphasises the role of dolomitic-carbonatitic melt as a predicted vehicle of metasomatism and melt fluxing in the mantle wedge overlying the subducted slab. 2) The geographic position of the carbonatitic occurrences $[4,5,98]$ in relation to the potassic and ultrapotassic magmatism [77 and references therein] and the assumed Italian subducted trench (i.e., [99 and references therein]). 3) The amount of Mesozoic carbonatic sediment apparently subducted below the Italian peninsula [e.g., 100] from which it can be inferred that the carbonatitic occurrences in Italy may be related to subduction processes. However, the radiogenic $\left({ }^{87} \mathrm{Sr} /{ }^{86} \mathrm{Sr}\right.$ ratio) and unradiogenic $\left({ }^{143} \mathrm{Nd} /{ }^{144} \mathrm{Nd}\right.$ ratio) isotopic signature requires a contribution from ter- 
rigenous-pelagic sediments probably through a fluid phases separating from the slabs and hydrating the mantles above it [e.g., 101] given the isotope data on Appenine limestones $\left({ }^{87} \mathrm{Sr} /{ }^{86} \mathrm{Sr} \sim 0.707460 ;{ }^{143} \mathrm{Nd} /{ }^{144} \mathrm{Nd} \sim\right.$ 0.511824 ) which are quite different from the Italian ( $\mathrm{Sr}-$ $\mathrm{Nd}-\mathrm{Pb}$ ) carbonatitic signature. It is argued that the magmas were produced by partial melting of the upper mantle hybridized by melt and fluid derived by the slab in subduction. The evidence comes also from geochemical computations of multi-element patterns for melt in equilibrium with secondary cpx in mantle xenoliths (OIB example; [102]), compared to a carbonatite from Italy [4]. These indicate that rutile-bearing carbonated eclogite (subducted oceanic crust) is the likely source for metasomatic carbonate melts (features inherited by the multi-element patterns are enriched LILE and negative spikes for $\mathrm{Nb}$, $\mathrm{Ta}, \mathrm{Hf}, \mathrm{Zr}$ and $\mathrm{Ti}$, as in subduction related settings). In agreement with experiments and calculations [e.g., 103], the subducted oceanic crust undergoes subsolidus dehydration reactions at depths of $<100 \mathrm{~km}$, but does not decarbonate at the same time. Provided that the trace elements signature is not significantly modified by this dehydration, carbonated rutile-bearing eclogite may persist to considerable depths in the mantle. Intersection of this material with the carbonated eclogite solidus provides a ubiquitous deep source of metasomatising carbonate melt. Primary calcitic carbonatite magmas may be from shallower depths according to experiments of [61], [e.g., 104].

[105] demonstrate that low seismic velocities may also be considered as zones of melting without elevated temperatures; the low velocity zone $(\sim 70-150 \mathrm{~km}$ depth $)$ is caused by melting due to the presence of carbonate. Seismic imaging of deep low velocity regions may reveal the locations of old subducted crust. Moreover, [106] show that there is no evidence of deep mantle origin in oceanic volcanism (i.e., Hawaii and Iceland). Car- bonatitic occurrences and/or Ca-rich magmas have also been recognised in Tabar-Lihir-Tanga-Feni arc (Papua New Guinea), in the Northern Tonga arc, and western Shandong Province, China [92,107,108]. In addition, other evidence comes from the ultra-calcic magmas and/or island-arc ankaramites from arc system and experimental geochemical data ([109 and references therein, 110]; Figure 6).

The rise of carbonatitic melts has to be linked to the plate spreading processes above the mantle wedge particularly in Italy where the carbonatites post-date the extensional tectonic (late Miocene to Quaternary, [111,112 and references therein]. The carbonatitic melting regime in arc systems is also supported by carbonate recycling variation (higher $\mathrm{CO}_{2}$ closer to the trench) in volcanic arc ([113], Central American Arc, [114]; evidence in the Italian peninsula, [115]). According to [97] carbonatitic form at P-T conditions between the dense cold slab and the higher $\mathrm{T}$ and lower $\mathrm{P}$ of the mantle wedge [116,117]. Such environments would produce melt and fluid migration from the subducted slab into the peridotite mantle wedge [118] leading to the reaction and crystallisation at subsolidus conditions of pyroxene, garnet and phlogopite at depths $>$ than $95 \mathrm{~km}$. However, the relative abundances of primary $\mathrm{Cr}$-spinel in xenoliths in carbonaterich melilitic tuff from Monticchio [60,70] coupled with opx, cpx, phlogopite, amphibole and very rare garnet suggest a shallower origin for the Monticchio carbonatites.

Carbonatite melt may therefore form in the mantle wedge at $\mathrm{T}>935^{\circ} \mathrm{C}$ and/or coexist with a silicate regime of water-saturated-silicate solidus corresponding to temperatures between $970^{\circ} \mathrm{C}$ and $1020^{\circ} \mathrm{C}$ and pressures between 70 to $100 \mathrm{Km}$ (rutile-bearing eclogite and garnet lherzolite, [97] and references therein; [119], 2000, Dalton, personal communication). Further, [120] show experimentally that liquids coexisting with orthopyroxene, clinopyroxene, garnet, and carbonate mark the transition between $\mathrm{CO}_{2-}$, dolomite- and magnesite-bearing magmas between two P-T invariant points $\left(\mathrm{A}: 2.6 \mathrm{GPa}, 1230^{\circ} \mathrm{C}, \mathrm{B}\right.$ : $\left.4.8 \mathrm{GPa}, 1320^{\circ} \mathrm{C}\right)$. However, the [120] lherzolitic model can be used as a broad reference for the Italian carbonatites since the primary conditions of the Italian carbonitite sensu latu ought to be explained within this thermochemical system. In fact, the melting conditions applied to the Italian carbonitites in order to accept a subduction-related environment must be lower and in concordance with the model predicted by ([97], see his Figure 7.13a, and b). Such P-T melting conditions are obtained by invoking a $\mathrm{H}_{2} \mathrm{O}+\mathrm{CO}_{2}$ excess in the mantle wedge due to the descending slab. If the [97] model is correct in terms of melting conditions, the slab components added to the mantle wedge, and the condition of immiscibility, then a carbonatite melt highly and distinctively enriched in incompatible elements can form in the convergent-margin silicate system. Moreover, I have used the [120] work on CMAS- $\mathrm{CO}_{2}$ as a guide to possible carbonatite and correctly note that "real" arc mantle melting conditions must be at lower $\mathrm{T}$-because of $\mathrm{H}_{2} \mathrm{O}$, $\mathrm{Na}_{2} \mathrm{O}, \mathrm{FeO}$. The task is to consider the melting conditions for Peridotite- $\mathrm{H}_{2} \mathrm{O}$ (see Figure 7.4 in [97]) noting differences for refractory fertile and enriched mantle and water-saturated vs dehydration-melting (pargasite lherzolite), then adding $\mathrm{CO}_{2}$ (see Figure 7.5 in [97] and applying the phase relations to the inferred Italian arc or back arc environment and using a "high $\mathrm{fO}_{2}$ " assumption.

By "choosing" high $\mathrm{fO}_{2}$ you avoid $\mathrm{CH}_{4}$, and graphite and the application of Figure 7.5c from [97] and can focus on applying Figure 7.5b from [97] to Italian P-T profiles. Note also that Figure 7.2 from [97] is equivalent to the [120] CMAS- $\mathrm{CO}_{2}$ model but the role of $\mathrm{Na}_{2} \mathrm{O}$ is 

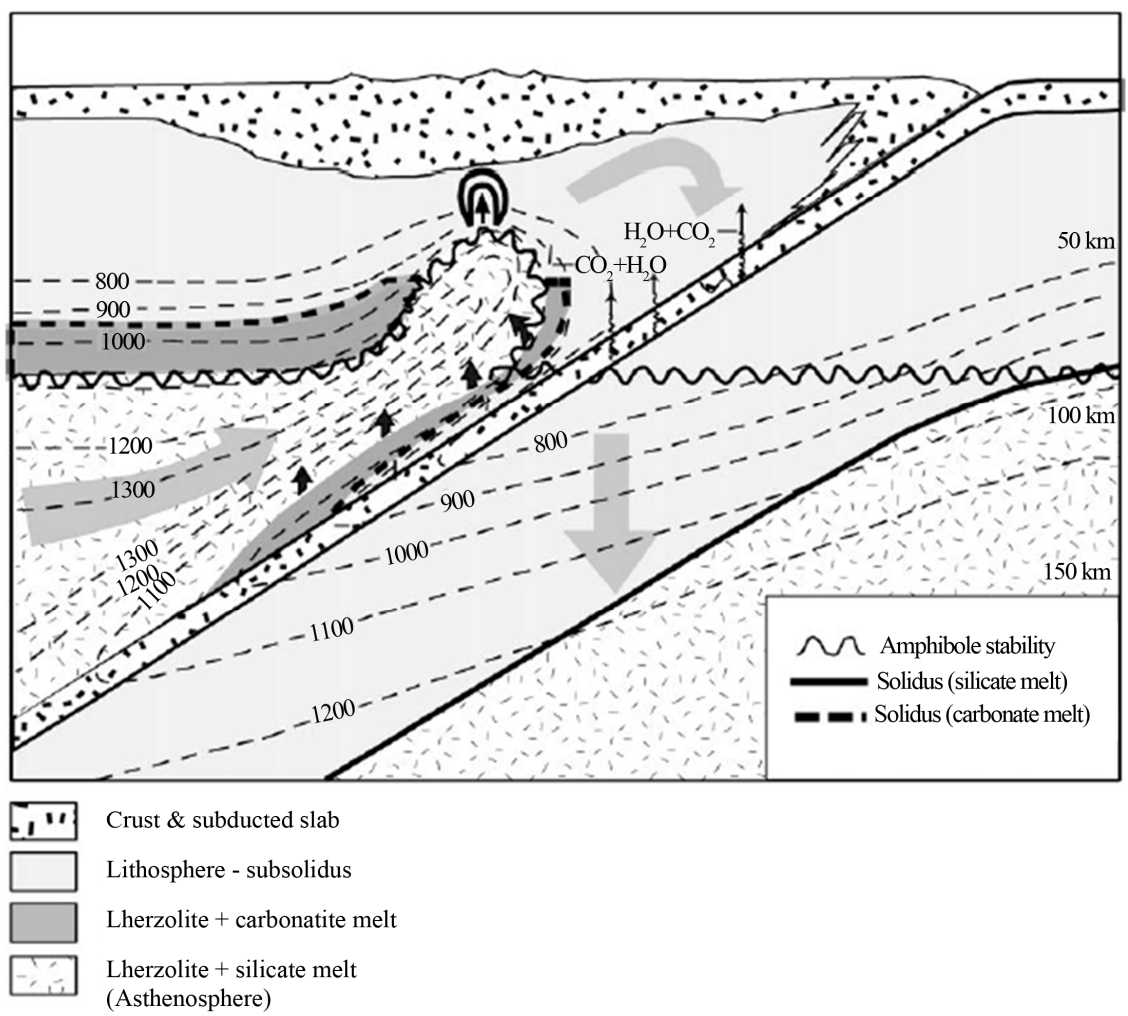

Figure 6. Schematic representation of subducted slab environment showing the (carbonatite-melt + lherzolite) region below the silicate melting region of peridotite $+\left(\mathrm{CO}_{2}+\mathrm{H}_{2} \mathrm{O}\right)$. The figure summarizes the combination of frist-stage melting, carbonatite metasomatism and diapirism of partially molten (silicate melt) peridotite suggested for carbonatitic regime (copied with permission from [97], Figure 7.13a).

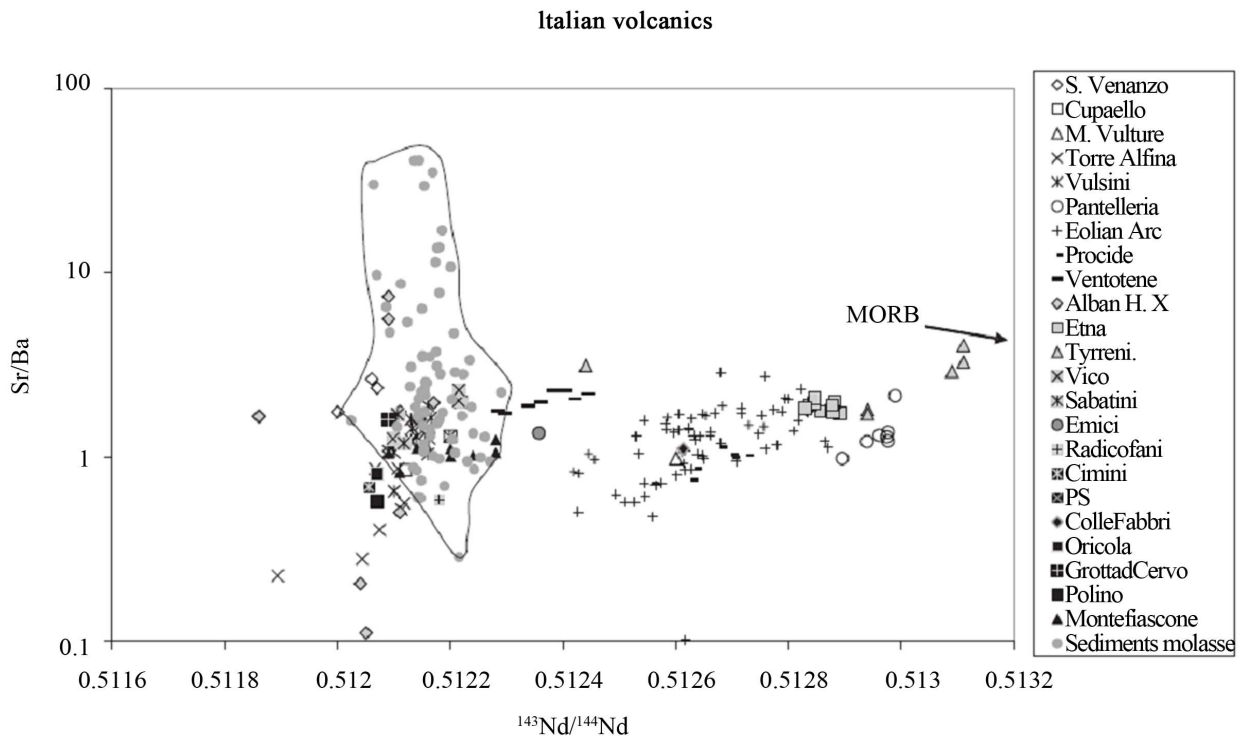

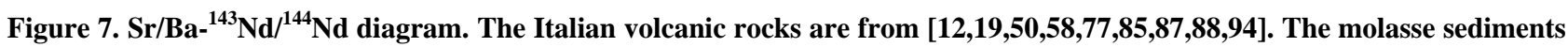
are from [136].

considerable, moving invariant point I6 to 2 Gpa, 1030 approximately. Note that in the subduction regime profile of Figure 7.13a and $b$ from [97] carbonatite magmas have a path to the surface avoiding capture in the silicate melting regime (e.g., the arc ankaramites of the [109] only if they lie either side of the upwelling wedge/silicate melting re- 
gime as could be the case in the Italian tectonic situation.

Evidence of immiscibility has been presented in the work of [121]. They show that combined silicate-carbonate melt inclusions in apatite phenocrysts occurred during magma evolution. Inclusions in the phenocrysts from an olivine-leucite phonolitic nephenilite bomb from Monticchio lake formation, record open system magma evolution during its rise towards the surface including crystallization, degassing, oxidation, and liquid immiscibility processes. [122] also point to immiscibility processes both at high $\mathrm{T}$, to form carbonatite and late stage immiscibility at relatevely low P-T $\left(670^{\circ} \mathrm{C}-800^{\circ} \mathrm{C} ;<1\right.$ $\mathrm{kb})$ to form ocelli in melilitolite groundmass. [49] explain the relationship between the kamafugite with the Ca-carbonatite rocks at Cupaello (Italy) with an origin from primary "kamafugitic" magmas providing evidence of immiscibility processes. [123] show that the immiscibility processes of the two-liquid silicate-carbonate can occur both at low and high pressure and the immiscibility two-liquid space is dependant on the amount of $\mathrm{CO}_{2}$ present in the system. The carbonate melt can migrate effectively only after separation from the silicate melt within liquid-dominated reservoirs (sills, dikes, or chambers) [124]. This intra-crustal environment may also be envisaged as the interface between upper mantle-lower crust and/or lower-intermediate crust where carbonated mantle derived magma can pond, stagnate, differentiate $[125,126]$ and can start up to the surface $(\sim 1 \mathrm{~Kb})$ to undergo to immiscibility processes with the formation of diatremic tuffsite at fast speeds of emplacement [127].

From $[4,86]$, the ITE (incompatible trace elements) patterns of the San Venanzo, Polino, Cupaello and Mt. Vulture carbonatitic occurrences and the related lavas are compared. It is further inferred that upper crustal contamination which would have resulted in dilution of the broad ITE carbonatitic pattern abundances with respect to the correspective lava was not important $[62,86]$. Other disagreements against Peccerillo hypothesis [e.g., 62] are expressed by [128,129].

An alternative mechanism to explain the carbonatitic ITE abundances is to invoke different partition coefficients for these elements which would have depended on the P-T and the melt chemistry. Such a hypothesis is in agreement with the [130] study which experimentally showed that a carbonatitic melt may broadly correspond to the near-solidus in CMAS- $\mathrm{CO}_{2}$ at $3 \mathrm{GPa}$ [120], similar to the melting of carbonated mantle lherzolite. Such melts have elevated incompatible trace elements, depletion of $\mathrm{Ti}$ and $\mathrm{Zr}$ and fractionated REE patterns similar to the broad geochemistry of the Italian carbonatites ([62,86 and references therein]).

From an overview of the major element carbonatitic data [5], the $\mathrm{Ca} /(\mathrm{Ca}+\mathrm{Mg})$ ratios ranges from 0.72 to 0.90 which provides minimum overlap with the $\mathrm{Ca} /(\mathrm{Ca}+$ $\mathrm{Mg}$ ) ratios experimentally produced by [61]. While the high $\mathrm{Ca} /(\mathrm{Ca}+\mathrm{Mg})$ values can be explained with intravolcanic suites fractionation processes, the lower values confirm the hypothesis of [61] that calciocarbonatitic melt are generated from lherzolitic, harzburgitic source at a $\mathrm{P}$ $>25$ kbar through carbonatite-metasomatism.

Further evidence of the connection between carbonatitic melts with subduction-related system have been noted by [131]. They suggest that carbonatitic melts can be an agent of mantle metasomatism producing relatively enriched trace elements (LILE, LREE and some HFSE). Such hypothesis is not in contrast with the general tectonic model of [99] and lately with [20] and [43]. Finally, carbonatitic rocks are formed by the accumulation of sedimentary material which can have a deep (OIB, subducted slab recycling in the upper-lower mantle producing the carbonation of the mantle, [1,113] or shallow origin (IAB, 70 - $100 \mathrm{~km}$ melting area; e.g., [92,108] depending on the tectonic system. Similarly, [132] confirmed the circuitous carbon pathways between the crust and some sources of carbonatitic magma in the mantle through the subduction system, involving carbon transport in a variety of phases. The material in the carbonated mantle wedge (eclogite and lherzolite) in the arc system is recycled into the deeper mantle linking hot spot and arc volcanoes erupting carbonatitic magma. Recently, [133] demonstrated experimentally that a hot slab could have produced a carbonatitic regime as it has occurred in Italy. Lately, a slab subduction recycling evidence in OIB may also be inferred from W-Os isotopes [134]. This compelling work rules out a simple core-mantle mixing scenario and suggests that the radiogenic osmium in ocean-island basalts can better be explained by the source of such basalts containing a component of recycled crust. [135] show that isotopic results in peridotite xenoliths in islands of Western Samoa and Austral (OIB) indicate that carbonatite-rich melts were derived from recycled cru- stal components in the convecting mantle.

Another hypothesis to consider is that the mantle wedge and/or upper mantle portion from which the Italian rocks originated underwent complex tectonic events such as the subduction of the European plate [26] before the subduction of the Adria plate in the most recent times. This tectonic succession would have influenced in a complex isotopic way the mantle wedge with an isotopic zonation from north to south. The $\mathrm{Sr} / \mathrm{Ba}^{-}{ }^{143} \mathrm{Nd} /{ }^{144} \mathrm{Nd}$ diagram (Figure 7) shows that the Alpine molasse sediments [136] have trace ( $\mathrm{Sr} / \mathrm{Ba}$ ratio) elements and unradiogenic $\mathrm{Nd}$ isotope ratios similar to the most enriched rocks of the Italian peninsula (Northern-central sector of the RMP). Thus, the source (mantle wedge) of the Italian volcanic rocks may be inferred to have been affected by the geochemical fluxing from the European and the Adria plate; and hence, the northern sector has been influenced by more intense metasomatism compared to the southern sector, where the isotopic trends $(\mathrm{Sr}-\mathrm{Nd}-\mathrm{Pb}$ and 
noble isotopes) come closer to the MORB-OIB values (Etna volcano-Iblean Plateu). Evidence of Carbonate metasomatism is also present at Finero (Ivrea zone-western Alps) and is shown by [137]. [138,139] link this metasomatism to a subduction setting.

The broad data from literature confirm a subduction related environment linking the ULUD, the Roman and Campanian Province within a unique tectonic system. However, even when the carbonatite are erupted in a distensional regime a component present into the mantle can derive from a residual slab subducted through the mantle $[105,132]$. Hence, further evidence of slabs recycling deep in the mantle and erupted in OIB is given by [134, 140-142]. The ubiquitous presence of slabs in the mantle which produce OIB magmatism is also supported by geochemical and geophysical studies [105,143 and references therein].

\section{Conclusion}

In the light of the new carbonatitic findings in Italy [5, 144-146], coupled with recent experimental work and geochemical and isotopic work on carbonatitic magmas, it is concluded that these carbonatitic volcanic rocks are related to the Roman Comagmatic Province. The relationship among the rocks, the rock ages and the distinctive character of the isotopic components in Italy suggest a tectonic structure (slab breakoff-slab window centered in north-central Italy) with the mixing by two mantle domains one above the Adria plate and another above the European plate. The two plates have metasomatised the above mantle by repeated dehydration and have mixed in various proportion the metasomatised mantles. This produced the vast isotopic variety rocks that are present on the Italian peninsula. The tomographic data may support such scenario (see references inside for major detail). The data coming from the OIB sites shows that a component from a recycled crust can be invoked to explain the presence of the carbonatite.

\section{Acknowledgements}

This work started during the Individual Post-doc Marie Curie Fellowship (EU grant, tutor: Chris Hawkesworth) at Bristol University (2001) as an off-hand project. I continued to work on this discontinuing project with a Postdoctoral Research Grant at the Università degli Studi di Napoli Federico II. Chris Hawkesworth, Dan Barker, David Green, Monica Piochi, Dean Presnall, Gianpiero Venturelli and Robert Ayuso are acknowledged for having perfected part of the manuscript. Any error in the manuscript has to be blamed to the author.

\section{REFERENCES}

[1] K. Hoernle, G. Tilton, M. Le Bas, S. Duggen and D.
Garge-Schongerg, "Geochemistry of Oceanic Carbonatites Compared with Continental Carbonatites: Mantle Recycling of Oceanic Crustal Carbonate," Contributions to Mineralogy and Petrology, Vol. 142, No. 5, 2002, pp. 520-542. doi:10.1007/s004100100308

[2] A. R. Woolley and B. Kjarsgaard, "Carbonatites of the World: Map and Database," 32nd International Geological Congress, Florence, 2004, p. 509.

[3] A. R. Woolley and A. A. Church, "Extrusive Carbonatites: A Brief Review," Lithos, Vol. 85, No. 1-4, 2005, pp. 1-14. doi:10.1016/j.lithos.2005.03.018

[4] G. Rosatelli and F. Stoppa, "European Carbonatites: Implications for the Subeuropean Mantle and Their Geohazard Potential," Periodico di mineralogia, Vol. 72, No.1, 2003, pp. 1-251.

[5] F. Stoppa and A. R. Woolley, "The Italian Carbonitites: Field Occurrence, Petrology and Regional Significance," Mineralogy and Petrology, Vol. 59, No. 1-2, 1997, pp. 43-67. doi:10.1007/BF01163061

[6] K. Bell and G. R. Tilton, "Probing the Mantle: The Story from Carbonatites," EOS, Vol. 83, No. 25, 2002, pp. 273277. doi:10.1029/2002EO000190

[7] A. R. Woolley, "Igneous Silicate Rocks Associated with Carbonatites: Their Diversity, Relative Abundances and Implications for Carbonatite Genesis," Periodico di Mineralogia, Vol. 72, No. 1, 2004, pp. 9-17.

[8] D. K. Bailey and J. D. Collier, "Carbonatite-Melilitite Association in the Italian Collision Zone and the Ugandan rifted Craton: Significant Common Factors," Mineralogical Magazine, Vol. 64, No. 4, 2000, pp. 675-682. doi:10.1180/002646100549698

[9] K. Bell, F. Castorina, G. Lavecchia, G. Rosatelli and F. Stoppa, "Is There a Mantle Plume below Italy?" EOS, Vol. 85, No. 50, 2004, pp. 541-547. doi:10.1029/2004EO500002

[10] K. Bell, G. LaVecchia and F. Stoppa, "Reasoning and Beliefs about Italian Geodynamics," Bollettino della Società Geologica Italiana, No. 5, 2005, pp. 119-127.

[11] A. Peccerillo and M. Lustrino, "Compositional Variations of Plio-Quaternary Magmatism in the Circum-Tyrrhenian area: Deep- vs Shallow-Mantle Processes," In: G. A. Foulger, J. H. Natland, D. C. Presnall and D. L. Anderson, Eds., Plates, Plumes and Paradigms, Geological Society of America, Boulder, 2005, pp. 421-434. doi:10.1130/0-8137-2388-4.421

[12] A. Peccerillo, "Plio-Quaternary Volcanism in Italy," Springer, Berlin, Heidelberg and New York, 2005, pp. 365.

[13] G. M. Yaxley and D. H. Green, "Experimental Demonstration of Refractory Carbonate-Bearing Eclogite and Siliceous Melt in the Subduction Regime," Earth and Planetary Science Letter, Vol. 128, No. 3-4, 1994, pp. 313-325. doi:10.1016/0012-821X(94)90153-8

[14] T. Hammonda, "High-Pressure Melting of Carbonated Eclogite and Experimental Constraints on Carbon Recycling and Storage in the Mantle," Earth and Planetary Science Letter, Vol. 214, No. 1-2, 2003, pp. 357-368. doi:10.1016/S0012-821X(03)00361-3 
[15] G. M. Yaxley and G. P. Brey, "Phase Relations of Carbonate-Bearing Eclogite Assemblages from 2.5 to 5.5 GPa: Implications for Petrogenesis of Carbonatites," Contributions to Mineralogy and Petrology, Vol. 146, No. 5, 2004, pp. 606-619. doi:10.1007/s00410-003-0517-3

[16] R. Dasgupta, M. M. Hirschmann and A. C. Withers, "Deep Global Cycling of Carbon Constrained by the Solidus of Anhydrous, Carbonated Eclogite under Upper Mantle Conditions," Earth and Planetary Science Letter, Vol. 227, No. 1-2, 2004, pp. 73-85. doi:10.1016/j.epsl.2004.08.004

[17] G. Serri, F. Innocenti and P. Manetti, "Geochemical and Petrological Evidence of the Subduction of Delaminated Adriatic Continental Lithosphere in the Genesis of the Neogene-Quaternary Magmatism of Central Italy," Tectonophysics, Vol. 223, No. 1-2, 1993, pp. 117-147. doi:10.1016/0040-1951(93)90161-C

[18] A. Peccerillo, "Plio-Quaternary Magmatism in Italy," Episodes 26, No. 3, 2004, pp. 222-226.

[19] L. Beccaluva, G. Bianchini and F. Siena, "Tertiary- Quaternary Volcanism and Tectonic-Magmatic Evolution," In: V. Grescenti, S. D’Offizi, S. Merlino and L. Sacchi, Eds., Geology of Italy, Special Volume of the Italian Geological Society, Rome, 2004, pp. 153-160.

[20] M. P. Marani, F. Gamberi and E. Monatti, "From Seafloor to Deep Mantle: Architecture of the Tyrrhenian Backarc Basin," Memorie Descrittive Della Carta Geologica d'Italia, Vol. 64, 2004, p. 194.

[21] F. Stoppa and G. Lavecchia, "Late Pleistocene UltraAlkaline Magmatic Activity in the Umbria Latium Region (Italy): An Overview," Journal of Volcanology and Geothermal Research, Vol. 52, No. 4, 1992, pp. 227-293. doi:10.1016/0377-0273(92)90049-J

[22] G. Lavecchia and F. Stoppa, "The Tectonic Significance of Italian Magmatism: An Alternative View to the Popular Interpretation," Terra Nova, Vol. 8, No. 5, 1996, pp. 435-446.

[23] G. Lavecchia, F. Stoppa and N. Creati, "Carbonatites and Kamafugites in Italy: Mantle-Derived Rocks that Challenge Subduction," Annals of Geophysics, Vol. 49, No. 1, 2005, pp. 389-402.

[24] W. Spakman and R. Wortel, "Tomographic View on Western Mediterranean Geodynamics," 32nd International Geographical Congress, Florence, 2004, pp. 31-52.

[25] M. J. R. Wortel, M. J. Van Bergen, D. M. A. Van De Zedde and W. Spakman, "Continental Collision, Slab Detachment and Post-Collisional K-Rich Magmatism: Central-Southern Italy as a Type Example," The 32nd International Geographical Congress, Florence, 2004, pp.116.

[26] E. Kissling, W. Spakman, "Interpretation of Tomographic Images of Uppermost Mantle Structure: Example from the Western and Central Alps," Journal of Geodynamics, Vol. 21, No. 1, 1996, pp. 97-111. doi:10.1016/0264-3707(95)00029-1

[27] G. De Natale, C. Troise, F. Pingue, P. De Gori and C. Chiarabba, "Structure and Dynamics of the Somma-Vesuvius Volcanic Complex," Mineralogy and Petrology,
Vol. 73, No.1-3, 2001, pp. 5-22. doi: $10.1007 / \mathrm{s} 007100170007$

[28] P. De Gori, G. B. Cimini, C. Chiarabba, G. De Natale, C. Troise and A. Deschamps, "Teleseismic Tomography of the Campanian Volcanic Area and Surrounding Apenninic belt," Journal of Volcanology and Geothermal Research, Vol. 109, No. 1-3, 2001, pp. 55-75. doi:10.1016/S0377-0273(00)00304-8

[29] P. F. Lucente, C. Chiarabba and G. B. Cimini, "Tomographic Constraints on the Geodynamic Evolution of the Italian Region," Journal of Geophysical Research, Vol. 104, No. B9, 1999, pp. 20307- 20327. doi:10.1029/1999JB900147

[30] E. Carminati, M. J. R. Wortel, W. Spakman and R. Sabadini, "The Role of Slab Detachment Processes in the Opening of the Western-Central Mediterranean Basins: Some Geological and Geophysical Evidence," Earth and Planetary Science Letter, Vol. 160, No. 3-4, 1998, pp. 651-665. doi:10.1016/S0012-821X(98)00118-6

[31] G. Selvaggi and A. Amato, "Subcrustal Earthquakes in the Northern Apennines (Italy): Evidence for a Still Active Subduction?" Geophysical Research Letters, Vol. 19, No. 21, 1992, pp. 2127-2130. doi:10.1029/92GL02503

[32] A. Amato, C. Cimini and B. Alessandrini, "Struttura Del sistema Litosfera-Astenosfera Nell'Appenino Settentrionale da dati di Tomografia Sismica," Studi Geologici Camerti, Vol. S1, No. 1, 1991, 83-901991

[33] D. Giardini and M. Velona, "The Deep Sismicity of the Tyrrhenian Sea," Terra Nova, Vol. 3, No. 1, 1991, pp. 57-64. doi:10.1111/j.1365-3121.1991.tb00844.x

[34] H. J. Anderson and J. A. Jackson, "The Deep Seismicity of the Tyrrhenian Sea," Geophysical Journal International, Vol. 91, No. 3, 1987, pp. 613-637. doi:10.1111/i.1365-246X.1987.tb01661.x

[35] C. Gasparini, G. Iannacone, P. Scandone and R. Scarpa, "Seismotectonics of the Calabrian Arc," Tectonophysics, Vol. 84, No.2-4, 1982, pp. 267-286. doi:10.1016/0040-1951(82)90163-9

[36] C. Doglioni, F. Mongelli, G. P. Pialli, "Boudinage of the Alpine Belt in the Apenninic Back-Arc," Memorie Descrittive Della Carta Geologica d'Italia, Vol. 52, 1998, pp. 457-468.

[37] E. Gueguen, C. Doglioni and M. Fernandez, "Lithospheric Boudinage in the Western Mediterranean BackArc Basins," Terra Nova, Vol. 9, No. 4, 1997, pp. 184187. doi:10.1046/j.1365-3121.1997.d01-28.x

[38] A. Peccerillo, G. Poli and C. Donati, "The Plio-Quarternary Magmatism of Southern Tuscany and Northern Latium: Compositional Characteristics, Genesis and Geodynamic Significance," Ofioliti, Vol. 26, No. 2a, 2001, pp. 229-238.

[39] Bulletin of the International Seismological Centre, "ISC Bulletin 1996 (Revised). ISC Catalogne 1964-1996,” 1996.

[40] M. Boccaletti, P. Elter and G. Guazzone, "Plate Tectonics Model for the Development of the Western Alps and Northern Apennines," Nature, Vol. 234, No. 49, 1971, pp. 108-111.

[41] G. Pialli, M. Barchi, G. Minelli, "Results of the CROP03 
Deep Seismic Profile," Memorie Descrittive Della Carta Geologica d'Italia, Vol. 52, 1998, pp. 657-671.

[42] I. R. Finetti, M. Boccaletti, M. Bonini, A. Del Ben, R. Geletti, M. Pipan and F. Sani, "Crustal Section Based on CROP Seismic Data across the North Tyrrhenian Northern Apennines-Adriatic Sea," Tectonophysics, Vol. 343, No. 3-4, 2001, pp. 135-163. doi:10.1016/S0040-1951(01)00141-X

[43] C. Doglioni, P. Harabaglia, S. Merlini, F. Mongelli, A. Peccerillo and C. Piromallo, "Orogens and Slabs VS. Their Direction of Subduction," Earth-Science Reviews, Vol. 45, No. 3-4, 1999, pp. 167-208. doi:10.1016/S0012-8252(98)00045-2

[44] A. Peccerillo and P. Manetti, "The Potassium Alkaline Volcanism of Central-Southern Italy: A Review of the Data Relevant to Petrogenesis and Tectonic Significance," Transactions of the Geological Society of South Africa, Vol. 88, No. 2, 1985, pp. 379-394.

[45] L. I. Panina, F. Stoppa and L. M. Usol'tseva, "Genesis of Melilitite Rocks of Pian di Celle Volcano, Umbrian Kamafugite Province, Italy: Evidence from Melt Inclusions in Minerals," Petrology, Vol. 11, No. 4, 2003, pp. 365-382.

[46] G. Di Battistini, A. Montanini, L. Vernia, G. Venturelli and S. Tonarini, "Petrology of Melilite-Bearing Rocks from the Montefiascone Volcanic Complex (Roman Magmatic Province): New Insights into the Ultrapotassic Volcanism of Central Italy," Lithos, Vol. 59, No. 1-2, 2001, pp. 1-24. doi:10.1016/S0024-4937(01)00054-8

[47] M. Federico, A. Peccerillo, M. Barbieri and T. W. Wu, "Mineralogical and Geochemical Study of Granular Xenoliths from Alban Hills Volcano, Central Italy: Bearing on Evolutionary Processes in Potassic Magma Chambers," Contributions to Mineralogy and Petrology, Vol. 115, No. 4, 1994, pp. 384-401. doi:10.1007/BF00320973

[48] F. Stoppa, "The San Venanzo Maar and Tuff Ring, Umbria, Italy: Eruptive Behaviour of a CarbonatiteMelilitite Volcano," Bulletin of Volcanology, Vol. 57, No. 7, 1996, pp. 563-577.

[49] F. Stoppa and A. Cundari, "A New Italian Carbonatite Occurrence at Cupaello (Rieti) and Its Genetic Significance," Contributions to Mineralogy and Petrology, Vol. 122, No. 3, 1995, pp. 275-288. doi: $10.1007 / \mathrm{s} 004100050127$

[50] F. Stoppa, A. Cundari, G. Rosatelli and A. Woolley, "Leucite Melilitolites in Italy: Genetic Aspects and Relationship with Associated Alkaline Rocks and Carbonatites," Periodico di Mineralogia, Vol. 72, No. 1, 2003, pp. 223-251.

[51] F. Stoppa, "L'Euremite di Colle Fabbri (Spoleto) un Litotipo ad Affinità Carbonatitica in Italia," Bollettino della Società Geologica Italiana, Vol. 107, No. 1, 1988, pp. 239248.

[52] L. Melluso, S. Conticelli, M. D’Antonio, N. P. Mirco and E. Saccani, "Petrology and Mineralogy of Wollastoniteand Melilite-Bearing Paralavas from the Central Apennines, Italy," American Mineralogist, Vol. 88, No. 8-9, 2003, pp. 1287-1299.
[53] F. Stoppa, G. Rosatelli, A. Cundari, F. Castorina and A. R. Woolley, "Comments on Melluso et al. (2003) and Their Reported Data and Interpretation of Some Wollastoniteand Melilite-Bearing Rocks from the Central Apennines of Italy," American Mineralogist, Vol. 90, No. 11-12, 2005, pp. 1919-1925. doi:10.2138/am.2005.398

[54] F. Capitanio, "Mineralogic and Bulk Rock Composition of Italian Wollastonite- and Melilite-Bearing Paralava and Clinker: Further Evidence of Their Pyrometamorphic Nature," American Mineralogist, Vol. 90, No. 11-12, 2005, pp. 1940-1944. doi:10.2138/am.2005.403r

[55] F. Capitanio, F. Larocca and S. Improta, "High-Temperature Rapid Pyrometamorphism Induced by Charcoal Pit Burning: The Case of Ricetto, Central Italy," International Journal of Earth Sciences, Vol. 93, No. 1, 2004, pp. 107-118. doi:10.1007/s00531-003-0374-3

[56] F. Stoppa and L. Lupini, "Mineralogy and Petrology of the Polino Monticellite Calciocarbonatite (Central Italy)," Mineralogy and Petrology, Vol. 49, No. 3-4, 1993, pp. 213-231. doi:10.1007/BF01164595

[57] F. Stoppa, A. R. Woolley and A. Cundari, "Extention of the Melilite-Carbonatite Province in the Apennines of Italy: The Kamafugite of Grotta del Cervo, Abruzzo," Mineralogical Magazine, Vol. 66, No. 4, 2002, pp. 555574. doi:10.1180/0026461026640049

[58] F. Stoppa, G. Rosatelli, F. Wall and T. Jeffries, "Geochemistry of Carbonate-Silicate Pairs in Nature: A Case History from Central Italy," Lithos, Vol. 85, No. 1-4, 2005, pp. 26-47. doi:10.1016/j.lithos.2005.03.026

[59] F. Stoppa and C. Principe, "Eruption Style and Petrology of a New Carbonatitic Suite from the Mt Vulture (Southern Italy): The Monticchio Lakes Formation," Journal of Volcanology and Geothermal Research, Vol. 80, No. 1, 1998, pp. 137-153.

[60] A. P. Jones, T. Kostoula, F. Stoppa and A. R. Woolley, "Petrography and Mineral Chemistry of Mantle Xenoliths in a Carbonate-Rich Melilitic Tuff from Mt. Vulture Volcano, Southern Italy," Mineralogical Magazine, Vol. 64, No. 4, 2000, pp. 593-613. doi:10.1180/002646100549634

[61] J. A. Dalton and B. J. Wood, "The Compositions of Primary Carbonate Melts and Their Evolution through Wallrock Reaction in the Mantle," Earth and Planetary Science Letters, Vol. 119, No. 4, 1993, pp. 511-525. doi:10.1016/0012-821X(93)90059-I

[62] A. Peccerillo, "Carbonate-Rich Pyroclastic Rocks from Central Apennines: Carbonatites or Carbonated Rocks? A Commentary," Mineralogy and Petrology, Vol. 73, No. 1, 2004, pp. 165-175.

[63] C. J. Hawkesworth, S. Turner, D. Peate, F. McDermott and P. van Calsteren, "Elemental U and Th Variations in Island Arc Rocks: Implications for U-Series Isotopes," Chemical Geology, Vol. 139, No. 1-4,1997, pp. 207-221. doi:10.1016/S0009-2541(97)00036-3

[64] C. J. Hawkesworth and R. Vollmer, "Crustal Contamination versus Enriched Mantle: $143 \mathrm{Nd} / 144 \mathrm{Nd}$ and 87Sr/86Sr Evidence from the Italian Volcanics," Contributions to Mineralogy and Petrology, Vol. 69, No. 2, 1979, pp. 151-165. doi:10.1007/BF00371858 
[65] F. Castorina, F. Stoppa, A. Cundari and M. Barbieri, "An Enriched Mantle Source for Italy's Melilitite-Carbonatite Association as Inferred by Nd-Sr Isotope Signature," Mineralogical Magazine, Vol. 64, No. 4, 2000, pp. 625639. doi:10.1180/002646100549652

[66] X. Yu, Z. Zhao, X. Mo, S. Su, D. Zhu and Y. Wang, "The Petrological and Mineralogical Characteristics of Cenozoic Kamafugite and Carbonatite Association in West Qinling, Gansu Province: China," Periodico di Mineralogia, Vol. 72, No. 72, 2003, pp. 161-179.

[67] V. V. Sharygin and F. Stoppa, "Silicate Melt Inclusions in Minerals of Anorthite-Wollastonite-Clinopyroxene Rock at Colle Fabbri (Italy)," ECROFI Meeting, 2005.

[68] K. Bell and J. Blenkinsop, "Neodymium and Strontium Isotope Geochemistry of Carbonatites," In: K. Bell, Ed., Carbinatites: Genesis and Evolution, Unwin-Hyman, London, 1989, pp. 278-300.

[69] K. Bell and J. Blenkinsop, "Nd and Sr Isotopic Compositions of Eastern African Carbonatites: Implications for Mantle Heterogeneity," Geology, Vol. 15, No. 2, 1987, pp. 99-102. doi:10.1130/0091-7613(1987)15<99:NASICO>2.0.CO;2

[70] H. Downes, T. Kostoula, A. P. Jones, A. D. Beard, M. F Thirlwall and J. L. Bodinier, "Geochemistry and Sr-Nd Isotopic Compositions of Mantle Xenoliths from the Monte Vulture Carbonatite-Melilitite Volcano, Central Southern Italy," Contributions to Mineralogy and $\mathrm{Pe}$ trology, Vol. 144, No. 1, 2002, pp. 78-92. doi:10.1007/s00410-002-0383-4

[71] R. A. Ayuso, B. De Vivo, G. Rolandi, R. Seal and A. Paone, "Geochemical and Isotopic (Nd-Pb-Sr-O) Variations Bearing on the Genesis of Volcanic Rocks from Vesuvius, Italy," Journal of Volcanology and Geothermal Research, Vol. 82, No. 1-4, 1998, pp. 53-78. doi:10.1016/S0377-0273(97)00057-7

[72] A. Paone, "Evidence of Crustal Contamination, Sediment, and Fluid Components in the Campanian Volcanic Rocks," Journal of Volcanology and Geothermal Research, Vol. 138, No. 1-2, 2004, pp. 1-26. doi:10.1016/i.jvolgeores.2004.06.004

[73] K. Bell, F. Castorina, G. Rosatelli and F. Stoppa, "Plume activity, Magmatism, and the Geodynamic Evolution of the Eastern Mediterranean," Annals of Geophysics, Vol. 49, No. 1, 2006, pp. 357-371.

[74] D. R. Hilton, T. P. Fischer and B. Marty, "Noble Gases and Volatile Recycling at Subduction Zones," Reviews in Mineralogy and Geochemistry, Vol. 47, No. 1, 2002, pp. 319-370. doi:10.2138/rmg.2002.47.9

[75] S. Nakai, H. Wakita, M. P. Nuccio and F. Italiano, "MORB-Type Neon in an Enriched Mantle beneath Etna, Sicily," Earth and Planetary Science Letters, Vol. 153, No. 1-2, 1997, pp. 57-66. doi:10.1016/S0012-821X(97)00161-1

[76] D. Tedesco, K. Nakao and P. Scarsi, "Noble Gas Isotopic Ratios from Historical Lavas and Fumaroles at Mount Vesuvius (Southern Italy): Constraints for Current and Future Volcanic Activity," Earth and Planetary Science Letters, Vol. 164, No. 1-2, 1998, pp. 61-78. doi:10.1016/S0012-821X(98)00167-8
[77] S. Conticelli, M. D’Antonio, L. Pinarelli and L. Civetta, "Source Contamination and Mantle Heterogeneity in the Genesis in the Italian Potassic and Ultra Potassic Volcanic Rocks: Sr-Nd-Pb Isotope Data from Roman Province and Southern Tuscany," Mineralogy and Petrology, Vol. 74, No. 2-4, 2002, pp. 189-222. doi: $10.1007 / \mathrm{s} 007100200004$

[78] A. Peccerillo and G. Panza, "Upper Mantle Domains beneath Central-Southern Italy: Petrological Effects, Timing and Geodynamic Implications," Geology, Vol. 27, No. 4, 1999, pp. 315-318. doi:10.1130/0091-7613(1999)027<0315:MMMICS $>2.3$. $\mathrm{CO} ; 2$

[79] F. Stoppa, "Consensus and Open Questions about Italian CO2-Driven Magma from the Mantle," Periodico di Mineralogia, Vol. 72, No. 72, 2003, pp. 1-8.

[80] G. Rosatelli, F. Stoppa and A. P. Jones, "Intrusive Calcite-Carbonatite Occurrence from the Vulture Volcano, Southern Italy," Mineralogical Magazine, Vol. 64, No. 4, 2000, pp. 155-164. doi:10.1180/002646100549643

[81] R. L. Hay and J. R. O'Neil, "Carbonatite Tuffs in the Laetolil beds of Tanzania and the Kaiserstuhl in Germany," Contributions to Mineralogy and Petrology, Vol. 82, No. 4, 1983, pp. 403-406. doi:10.1007/BF00399717

[82] H. W. Hubberten, K. Katz-Lehnert and J. Keller, "Carbon and Oxygen Isotope Investigations in Carbonatites and Related Rocks from the Kaiserstuhl, Germany," Chemical Geology, Vol. 70, No. 3, 1988, pp. 257-274. doi:10.1016/0009-2541(88)90097-6

[83] T. R. Riley, D. K Bailey, R. E. Harmer, H. Liebsch, F. E. Lloyd and M. R. Palmer, "Isotopic and Geochemical Investigation of a Carbonatite-Syenite-Phonolite Diatreme, West Eifel (Germany)," Mineralogical Magazine, Vol. 63, No. 5, 1999, pp. 615-631. doi:10.1180/002646199548736

[84] I. O. Onuonga, A. E. Fallick and P. Bowden, "The Recognition of Meteoric-Hydrothermal and Supergene Processes in Volcanic Carbonatites, Nyanza Rift, Western Kenya, Using Carbon and Oxygen Isotopes," Journal of African Earth Sciences, Vol. 25, No. 1, 1997, pp. 103-113. doi:10.1016/S0899-5362(97)00064-X

[85] N. W. Rogers, C. J. Hawkesworth, R. J. Parker and J. S., Marsh, "The Geochemistry of Potassic Lavas from the Vulsini, Central Italy and Implications for Mantle Enrichment Processes in the Upper Mantle," Journal of Volcanology and Geothermal Research, Vol. 50, No. 1-2, 1985, pp. 85-99. doi:10.1016/0377-0273(92)90038-F

[86] A. Peccerillo, "Relationships between Ultrapotassic and Carbonate-Rich Volcanic Rocks in Central Italy: Petrogenetic and Geodynamic Implications," Lithos, Vol. 43, No. 4, 1998, pp. 267-279. doi:10.1016/S0024-4937(98)00016-4

[87] R. M. Ellam, C. J. Hawkesworth, M. A. Menzies and N. W. Rogers, "The Volcanism of Southern Italy: Role of Subduction and Relationship between Potassic and Sodic Alkaline Magmatism," Journal of Geophysical Research, Vol. 94, No. B4, 1989, pp. 4589-4601. doi:10.1029/JB094iB04p04589

[88] M. D’Antonio, L. Civetta and P. Di Girolamo, "Mantle 
Source Heterogeneity in the Campanian Region (South Italy) as Inferred from Geochemical and Isotopic Features of Mafic Volcanic Rocks with Shoshonitic Affinity," Mineralogy and Petrology, Vol. 67, No. 3-4, 1999, pp. 163-192. doi:10.1007/BF01161520

[89] L. Beccaluva, G. Bianchini, C. Bonadiman, F. Siena and C. Vaccaro, "Coexisting Anorogenic and Subduction-Related Metasomatism in Mantle Xenoliths from the Betic Cordillera (Southern Spain)," Lithos, Vol. 75, No. 1-2, 2004, pp. 67-87. doi:10.1016/j.lithos.2003.12.015

[90] K. Bell, "Carbinatites: Genesis and Evolution," Unwin-Hyman, London, 1989, p. 618.

[91] I. Hornig-Kjarsgaard, "Rare Earth Elements in Sovitic Carbonatites and Their Mineral Phases," Journal of Petrology, Vol. 39, No. 11-12, 1998, pp. 2105-2221. doi:10.1093/petrology/39.11.2105

[92] J. Ying, X. Xinhua and H. Zhang, "Geochemical and Isotopic Investigation of the Laiwu-Zibo Carbonatites from Western Shandong Province, China, and Implications for Their Petrogenesis and Enriched Mantle Source," Lithos, Vol. 75, No. 3-4, 2004, pp. 413-426. doi:10.1016/j.lithos.2004.04.037

[93] K. Bell and G. R. Tilton, "Probing the Mantle: The Story from Carbonatites," EOS, Vol. 83, No. 25, 2002, pp. 273277. doi:10.1029/2002EO000190

[94] D. Gasperini, J. Blichert-Toft, D. Bosch, A. Del Moro, P. Macera and F. Albarede, "Upwelling of Deep Mantle Material through a Plate Window: Evidence from the Geochemistry of Italian Basaltic Volcanics," Journal of Geophysical Research, Vol. 107, 2002, pp 1-19. doi:10.1029/2001JB000418

[95] W. Spakam, S. van der Lee, R. van der Hilst, "Travel-time Tomography of the European-Mediterranean Mantle down to $1400 \mathrm{Km}$," Physics of the Earth and Planetary Interiors, Vol. 79, No. 1-2, 1993, pp. 3-74. doi:10.1016/0031-9201(93)90142-V

[96] M. J. R. Wortel and W. Spakman, "Subduction and Slab Detachment in the Mediterranean-Carpathian Region," Science, Vol. 290, No. 5498, 2000, pp. 1910-1917. doi:10.1126/science.290.5498.1910

[97] D. H. Green and T. J. Falloon, "Pyrolite: A Ringwood Concept and Its Current Expression," In: I. N. S. Jackson, Ed., The Earth's Mantle: Composition, Structure, and Evolution, Cambridge University Press, Cambridge, 1998, pp. 311-380.

[98] F. Stoppa, G. Rosatelli, F. Wall and T. Jeffries, "Carbonate-Silicate Relationships in Italian Carbonatites: Comparison within and between Occurrences," Eurocarb workshop 2002, 2002, pp. 30-32.

[99] G. Serri, F. Innocenti and P. Manetti, "Geochemical and Petrological Evidence of the Subduction of Delaminated Adriatic Continental Lithosphere in the Genesis of the Neogene-Quaternary Magmatism of Central Italy," Tectonophys, Vol. 223, No. 1-2, 1993, pp. 117-147. doi:10.1016/0040-1951(93)90161-C

[100] P. Scandone, "Origin of Tyrrhenian Sea and Calabrian arc," Bollettino della Società Geologica Italiana, Vol. 98, No. 1, 1979, pp. 27-34.

[101] C. Class, D. M. Miller, S. L. Goldstein and C. H. Lang- muir, "Distinguishing Melt and Fluid Subduction Components in Umnak Volcanics, Aleutian Arc," Geochemistry, Geophysics, Geosystems, Vol. 1, 2000, Paper No. 1999GC000010.

[102] M. Coltorti, R. Bonadiman, W. Hinton, F. Siena and B. G. J. Upton, "Carbonatite Metasomatism of the Oceanic Upper Mantle: Evidence from Clinopyroxenes and Glasses in Ultramafic Xenoliths of Grande Comore, Indian Ocean," Journal of Petrology, Vol. 40, No. 1, 1999, pp. 133-165. doi:10.1093/petroj/40.1.133

[103] J. F. Molina and S. Poli, "Carbonate Stability and Fluid Composition in Subducted Oceanic Crust: An Experimental Study on $\mathrm{H}_{2} \mathrm{O}-\mathrm{CO}_{2}$-Bearing Basalts," Earth and Planetary Science Letters, Vol. 176, No. 3-4, 2000, pp. 295-310. doi:10.1016/S0012-821X(00)00021-2

[104] D. K. Bailey, "Carbonate Magmas," Journal of the Geological Society, Vol. 150, No. 4, 1993, pp. 637-651. doi:10.1144/gsigs.150.4.0637

[105] D. C. Presnall and H. G. Gudfinnsson, "Carbonate-Rich Melts in the Oceanic Low-Velocity Zone and Deep Mantle," In: G. A. Foulger, J. H. Natland, D. C. Presnall and D. L. Anderson, Eds., Plates, Plumes and Paradigms Geological Society of America, Boulder, 2005, pp. $207-$ 216. doi:10.1130/0-8137-2388-4.207

[106] D. C. Presnall and H. G. Gudfinnsson, "Oceanic Volcanism from the Low-velocity Zone-without Mantle Plumes," Journal of Petrology, Vol. 52, No. 7-8, 2011, pp. 15331546. doi:10.1093/petrology/egq093

[107] T. J. Falloon and A. J. Crawford, "The Petrogenesis of Calcium Boninite Lavas Dredged from the Northern Tonga ridge," Earth and Planetary Science Letters, Vol. 102, No. 3-4, 1991, pp. 375-394. doi:10.1016/0012-821X(91)90030-L

[108] B. I. A. McInnes and E. M. Cameron, "Carbonated, Alkaline Hybridizing Melts from a Sub-Arc Environment: Mantle Wedge Samples from the Tabar-Lihir-Tanga-Feni Arc, Papua New Guinea," Earth and Planetary Science Letters, Vol. 122, No. 1-2, 1994, pp. 125-141. doi:10.1016/0012-821X(94)90055-8

[109] D. H. Green, M. W. Schmidt and W. O. Hibberson, "Island-Arc Ankaramites: Primitive Melts from Fluxed Refractory Lherzolitic Mantle," Journal of Petrology, Vol. 45, No. 2, 2004, pp. 391-403. doi:10.1093/petrology/egg101

[110] M. W. Schmidt, D. H. Green and W. O. Hibberson, "U1tra-Calcic Magmas Generated from Ca-depleted Mantle: An Experimental Study on the Origin of Ankaramites," Journal of Petrology, Vol. 45, No. 3, 2004, pp. 531-554. doi:10.1093/petrology/egg093

[111] G. Lavecchia, "The Tyrrhenian-Apennines System: Structural Setting and Seismotectogenesis," Tectonophysics, Vol. 147, No. 3-4, 1988, pp. 263-296. doi:10.1016/0040-1951(88)90190-4

[112] G. Lavecchia and P. Boncio, "Tectonic Setting of the Carbonatite-Melilitite Association of Italy," Mineralogical Magazine, Vol. 64, No. 4, 2000, pp. 583-592. doi:10.1180/002646100549625

[113] D. M. Kerrick and J. A. D. Connolly, "Subdaction of Ophicarbonates and Recycling of $\mathrm{CO}_{2}$ and $\mathrm{H}_{2} \mathrm{O}$," Geol- 
ogy, Vol. 26, No. 4, 1998, pp. 375-378. doi:10.1130/0091-7613(1998)026<0375:SOOARO $>2.3$.C $\underline{\mathrm{O} ; 2}$

[114] G. Snyder, R. Poreda, A. Hunt and U. Fehn, "Regional Variations in Volatile Composition: Isotopic Evidence for Carbonate Recycling in the Central American Volcanic arc," Geochemistry, Geophysics, Geosystems, Vol. 2, 2001, Paper No. 2001 GC000163.

[115] A. Minissale, "Origin, Transport and Discharge of $\mathrm{CO}_{2}$ in Central Italy," Earth-Science Reviews, Vol. 66, No. 1-2, 2004, pp. 89-141. doi:10.1016/j.earscirev.2003.09.001

[116] J. H. Davies and D. J. Stevenson, "Physical Model of Source Region of Subduction Zone Volcanics," Journal of Geophysical Research, Vol. 97, No. 5, 1992, pp. 20372070. doi:10.1029/91JB02571

[117] Y. Tatsumi and S. Eggins, "Subduction Zone Magmatism,” Blackwell Science, Cambridge, 1995, p. 211.

[118]R. M. Ellam and C. J. Hawkesworth, "Elemental and Isotopic Variations in Subduction Related Basalts: Evidence for a Three Component Model," Contributions to Mineralogy and Petrology, Vol. 98, No. 1, 1988, pp. 72-80. doi:10.1007/BF00371911

[119] J. A. Dalton and J. Blundy, "Carbonatites from Recycled Eclogites," The Journal of Conference Abstracts, Goldschmidt Conference, 2000, pp. 330.

[120] J. A. Dalton and D. C. Presnall, "The Continuum of Primary Carbonatitic-Kimberlitic Melt Compositions in Equilibrium with Lherzolite: Data from the System $\mathrm{CaO}-\mathrm{MgO}-\mathrm{Al}_{2} \mathrm{O}_{3}-\mathrm{SiO}_{2}-\mathrm{CO}_{2}$ at $6 \mathrm{GPa}$," Journal of Petrology, Vol. 39, No. 11-12, 1998, pp. 1953-1964.

[121] I. P. Solovova, A. V. Girnis, L. N. Kogargo, N. N. Kononkova, F. Stoppa and G. Rosatelli, "Compositions of Magmas and Carbonate-Silicate Liquid Immiscibility in the Vulture Alkaline Igneous Complex, Italy," Lithos, Vol. 85, No. 1-4, 2005, pp. 113-128. doi:10.1016/j.lithos.2005.03.022

[122] F. Stoppa, A. Cundari, G. Rosatelli and A. R. Woolley, "Leucite Melilitolites in Italy: Genetic Aspects and Relationships with Associated Alkaline Rocks and Carbonatites," Periodico di Mineralogia, Vol. 72, No. 1, 2003, pp. 223-251.

[123] R. A. Brooker, "The Effect of $\mathrm{CO}_{2}$ Saturation on Immiscibility between Silicate and Carbonate Liquids: An Experimental Study," Journal of Petrology, Vol. 39, No. 11-12, 1998, pp. 1905-1915.

[124] W. G. Minarik, "Complications to Carbonate Melt Mobility due to the Presence of an Immiscible Silicate," Journal of Petrology, Vol. 39, No. 11-12, 1998, pp. 19651973. doi:10.1093/petroj/39.11-12.1965

[125] C. Annen and R. S. J. Sparks, "Effects of Repetitive Emplacement of Basaltic Intrusions on Thermal Evolution and Melt Generation in the Deep Crust," Earth and Planetary Science Letters, Vol. 203, No. 3-4, 2002, pp. 937-955. doi:10.1016/S0012-821X(02)00929-9

[126] C. Annen, J. D. Blundy and R. S. J. Sparks, "The Genesis of Intermediate and Silicic Magmas in Deep Crustal Hot Zones," Journal of Petrology, Vol. 47, No. 3, 2006, pp. 505-539. doi:10.1093/petrology/egi084
[127] F. Stoppa, F. E. Lloyd and G. Rosatelli, " $\mathrm{CO}_{2}$ as the Virtual Propellant of Carbonatitic Conjugate Pairs and the Eruptions of Diatremic Tuffsite," Periodico di Mineralogia, Vol. 72, No. 1, 2003, pp. 205-222.

[128] D. K. Bailey, "Carbonate Volcanics in Italy: Numerical tests for the Hypothesis of Lava-Sedimentary Limestone Mixing," Periodico di Mineralogia, Vol. 74, No. 3, 2005, pp. 205-208.

[129] A. R. Woolley, F. Castorina, A. Cundari, G. Rosatelli, F. Stoppa and F. Wall., 'Reply to: Carbonate-Rich Pyroclastic Rocks from Central Apennines: Carbonatites or Carbonated Rocks? A Commentary'," Periodico di Mineralogia, Vol. 74, No. 3, 2005, pp. 183-194.

[130] J. Blundy and J. Dalton, "Experimental Comparison of Trace element Partitioning between Clinopyroxene and Melt in Carbonate and Silicate Systems, and Implications for Mantle Metasomatism," Contributions to Mineralogy and Petrology, Vol. 139, No. 3, 2000, pp. 356-371. doi:10.1007/s004100000139

[131] R. J. Sweeney, D. H. Green and S. H. Sie, "Trace and Minor Element Partitioning between Garnet and Amphibole and Carbonatite Melt," Earth and Planetary Science Letters, Vol. 113, No. 1-2, 1992, pp. 1-14. doi:10.1016/0012-821X(92)90207-C

[132] D. S. Barker, "Consequences of Recycled Carbon in Carbonatites," Canadian Mineralogist, Vol. 34, No. 2, 1996, pp. 373-387.

[133] K. Tusno and R. Dasgrupta, "Melting Phase Relation of Nominally Anhydrous, Carbonated Pelitic-Eclogite at 2.5-3.0 GPa and Deep Cycling of Sedimentary Carbon," Contributions to Mineralogy and Petrology, Vol. 161, No. 5, 2011, pp. 743-763. doi:10.1007/s00410-010-0560-9

[134] A. Schersten, T. Elliott, C. J. Hawkesworth and M. Norman, "Tungsten Isotope Evidence that Mantle Plumes Contain No Contribution from the Earth'S Core," Nature, Vol. 427, No. 6971, 2005, pp. 234-237. doi:10.1038/nature02221

[135] E. H. Hauri, N. Shimizu, J. J. Dieu and S. R. Hart, "Evidence for Hotspot-Related Carbonatite Metasomatism in the Oceanic Upper Mantle," Nature, Vol. 365, No. 6443, 1993, pp. 221-227. doi:10.1038/365221a0

[136] P. Henry, E. Deloule and A. Michard, "The Erosion of the Alps: Nd Isotopic and Geochemical Constraints on the Sources of the Peri-Alpine Molasse Sediments," Earth and Planetary Science Letters, Vol. 146, No. 3-4, 1997, pp. 627-644. doi:10.1016/S0012-821X(96)00252-X

[137] F. Zaccarini, E. F. Stumpfl and G. Garuti, "Zirconolite and $\mathrm{Zr}-\mathrm{Th}-\mathrm{U}$ Minerals in Chromitites of the Finero Complex, Western Alps, Italy: Evidence for CarbonatiteType Metasomatism in a Subcontinental Mantle Plume,' Canadian Mineralogist, Vol. 42, No. 6, 2004, pp. 18251845. doi:10.2113/gscanmin.42.6.1825

[138] A. Zanetti, M. Mazzucchelli, G. Rivalenti and R. Vannucci, "The Finero Phlogopite-Peridotite Massif: An Example of Subduction-Related Metasomatism," Contributions to Mineralogy and Petrology, Vol. 134, No. 2-3, 1999, pp. 107-122. doi:10.1007/s004100050472

[139] T. Morishita, S. Arai and A. Tamura, "Petrology of an Apatite-Rich Layer in the Finero Phlogopite-Peridotite, 
Italian Western Alps: Implications for Evolution of a Metasomatising Agent," Lithos, Vol. 69, No. 1-2, 2003, pp. 37-49. doi:10.1016/S0024-4937(03)00046-X

[140] B. L. N. Kennett and R. D. Van Der Hilst, "Seismic Structure of the Mantle: From Subduction Zone to Craton," In: I. N. Jackson, S. Ed., The Earth's Mantle: Composition, Structure, and Evolution, Cambridge University Press, Cambridge, 1998, pp. 381-404.

[141] J. H. Davies, J. P. Brodholt and B. J. Wood, "Chemical Reservoirs and Convection in the Earth's Mantle," Philosophical Transactions of the Royal Society, Vol. 360, No. 1800, 2002, pp. 2361-2648. doi:10.1098/rsta.2002.1086

[142] S. Klemme, J. D. Blundy and B. J. Wood, "Experimental Constraints on Major and Trace Element Partitioning during Partial Melting of Eclogite," Geochimica et Cosmochimica Acta, Vol. 66, No. 17, 2002, pp. 3109-3123. doi:10.1016/S0016-7037(02)00859-1

[143] A. Meibon and D. L. Anderson, "The Statistical Upper Mantle Assemblage," Earth and Planetary Science Letters, Vol. 217, No. 1-2, 2003, pp. 123-139. doi:10.1016/S0012-821X(03)00573-9

[144] M. D’Orazio, F. Innocenti, S. Tonarini and C. Doglioni, "Carbonatites in a Subduction System: The Pleistocene alvikites from Mt. Vulture (Southern Italy)," Lithos, Vol. 98, No. 1-4, 2007, pp. 313-334.

doi:10.1016/j.lithos.2007.05.004

[145]F. Stoppa, C. Principe and P. Giannandrea, "Comments on: Carbonatites in a Subduction System: The Pleistocene Alvikites from Mt. Vulture (Southern Italy)," "Lithos, Vol. 103, No.3-4, 2008, pp. 550-556.

[146] M. D’Orazio, F. Innocenti, S. Tonarini and C. Doglioni, "Reply to the Discussion of: 'Carbonatites in a Subduction System: The Pleistocene Alvikites from Mt. Vulture (southern Italy)' by D'Orazio, M., Innocenti, F., Tonarini, S., Doglioni, C. (Lithos. 98, 313-334) by F. Stoppa, C. Principe and P. Giannandrea," Lithos, Vol. 103, No. 3-4, 2008, pp. 557-561. doi:10.1016/j.lithos.2007.10.010

[147] A. Zindler and S. R. Hart, "Chemical Geodynamics," Annual Review of Earth and Planetary Science Letters, Vol. 14, 1986, pp. 493-571. doi:10.1146/annurev.ea.14.050186.002425

[148]H. Rollinson, "Using Geochemical Data: Evaluation, Presentation, Interpretation," Longman Scientific and Technical, England, 1993, p. 352. 